Summer 2015

\title{
Austerity, Debt Overhang, and the Design of International Standards on Sovereign, Corporate, and Consumer Debt Restructuring
}

Susan Block-Lieb

Fordham University School of Law, sblocklieb@law.fordham.edu

Follow this and additional works at: https://www.repository.law.indiana.edu/ijgls

Part of the International Law Commons, Law and Economics Commons, and the Transnational Law Commons

\section{Recommended Citation}

Block-Lieb, Susan (2015) "Austerity, Debt Overhang, and the Design of International Standards on Sovereign, Corporate, and Consumer Debt Restructuring," Indiana Journal of Global Legal Studies: Vol. 22 : Iss. 2 , Article 8.

Available at: https://www.repository.law.indiana.edu/ijgls/vol22/iss2/8

This Symposium is brought to you for free and open access by the Law School Journals at Digital Repository @ Maurer Law. It has been accepted for inclusion in Indiana Journal of Global Legal Studies by an authorized editor of Digital Repository @ Maurer Law. For more information, please contact rvaughan@indiana.edu.

\section{$\Psi$}

JEROME HALL LAW LIBRARY

INDIANA UNIVERSITY

Maurer School of Law
Bloomington 


\title{
Austerity, Debt Overhang, and the Design of International Standards on Sovereign, Corporate, and Consumer Debt Restructuring
}

\author{
SUSAN BLOCK-LIEB*
}

ABSTRACT

Following the Asian Financial Crisis, sovereign debt defaults prompted calls by the International Monetary Fund (IMF) for a statutory Sovereign Debt Restructuring Mechanism (SDRM). In promoting the SDRM, IMF leaders argued that countries' sovereign debt problems needed something like U.S. Chapter 11, which is to say that IMF leaders supported the SDRM proposal with reference to legal claims rather than relying on purely economic arguments about the welfare benefits of resolving debt overhang. Framing the debate in this way caught on, but by 2005 the IMF board of directors had rejected the SDRM proposal. The current Global Financial Crisis similarly has resulted in more than several sovereign borrowers' defaults and has, in turn, renewed calls for revision of the process for restructuring sovereign indebtedness. This time, however, the rhetoric has shifted away from legal metaphor. Rather than comparing sovereign borrowers to corporations in financial distress, sovereign debt has been discussed in terms reminiscent of household debt. Countries should, we are told, practice financial austerity. This paper unpacks the differences among indebtedness owed by public and private, corporate and consumer, borrowers, and the distinct implications for restructuring these different sorts of debt. It argues that modern economic literature on sovereign debt has been chasing the wrong metaphor. The puzzle of sovereign debt shifts when sovereign borrowing is viewed through the lens of consumer (not corporate) borrowing. This shift in metaphor promises more than a new rhetoric.

* Cooper Family Professor in Urban Legal Issues, Fordham University School of Law. Many thanks to Fred Aman and those in attendance at the Maurer School of Law conference on Law and the Globalization of Austerity for their encouragement and insights. Many additional thanks are owed to Yan Liu, Christoph Paulus, Mark Weidemaier, Iain Ramsay, and Joe Spooner for their comments, questions, and support.

Indiana Journal of Global Legal Studies Vol. 22 \#2 (Summer 2015)

C Indiana University Maurer School of Law 


\section{INTRODUCTION}

Sovereign debt defaults in the wake of the Asian Financial Crisis prompted calls by the International Monetary Fund (IMF) for a statutory Sovereign Debt Restructuring Mechanism (SDRM). In promoting the SDRM, IMF leaders argued that countries' debt problems needed something like U.S. Chapter $11 .^{1}$ Just as a Chapter 11 plan of reorganization binds dissenters to its terms, an SDRM would bind holdouts to a sovereign debt restructuring approved by an overwhelming majority. This was not the only reference to U.S. corporate reorganization laws as an international model for resolution of the debt problems that occurred during the Asian Financial Crisis. The G-22 had earlier encouraged countries to adopt a range of structural reforms to raise the level of their financial architecture, including proposals to reform domestic corporate insolvency laws to enable the restructuring of debt owed by financially viable businesses, and the IMF had embraced this contention that corporate insolvency laws should become more reorganization friendly. ${ }^{2}$ In proposing an SDRM, IMF leaders extended the logic of reforming corporate insolvency law to the treatment of unsustainable sovereign debt. ${ }^{3}$ The contention was not only that something like Chapter 11 would help prevent problems from bloated corporate indebtedness, but also that something like Chapter 11 could help resolve intractable sovereign debt problems.

The SDRM proposal was controversial-far more controversial than the notion that corporate insolvency law should be reformed to enable

1. See, e.g., ANNe O. KRUEger, InT'L Monetary Fund, A New APPROACH to SOVEREIGN DEBT RESTRUCTURING (2002), available at http://www.imf.org/external/pubs/ft/ exrp/sdrm/eng/sdrm.pdf (outlining a sovereign debt restructuring mechanism that addresses the shortcomings of the current framework for sovereign debt restructuringi.e., delays in seeking restructuring caused by the absence of a predictable restructuring process, the absence of majority voting mechanisms, and the risk of creditor holdouts).

2. See, e.g., Terence C. Halliday \& Bruce G. Carruthers, Bankrupt: Global LAWMAKING AND SYSTEMIC FINANCIAL CRISIS 141, 248-249 (2009) (noting that "the . . G22 . . made domestic bankruptcy law an integral component of international financial architecture," and "[ $t$ ]he IMF . . . maintained that reorganization would ... lead to orderly rehabilitation of companies in ways that would forestall national economic crises."); Susan Block-Lieb \& Terence C. Halliday, The Microeconomics and Macropolitics of Systemic Financial Crisis: Bankruptcy as a Point of Reference, in SOVEREIGN INSOLVENCY: POSSIBLE LEGAL SOLUTIONS (Jasna Garasic \& Nadia Bodiroga-Vukobrat eds., forthcoming 2015) (exploring the reasons for and consequences of the G-20's failure to reform insolvency laws in the aftermath of the current Global Financial Crisis).

3. See KRUEGER, supra note 1, at 10-13. 
reorganization of company debt. ${ }^{4}$ Comparing an SDRM to confirmation of a plan of reorganization was unconvincing to many; public and corporate debtors are distinct, as are the limits on the restructuring of sovereign and private commercial debts. Opponents to the SDRM also argued that the restructuring mechanism could create incentives for strategic action by sovereign borrowers and that contractual measures-such as collective action clauses in sovereign bond offerings-would sufficiently constrain holdouts. ${ }^{5}$

Although the SDRM debate was couched in terms of legal distinctions between corporate and sovereign debt restructurings, there were, of course, more political issues at stake. ${ }^{6}$ Within the U.S. Department of the Treasury, support had existed for an SDRM on the grounds that this mechanism would provide a means for limiting enthusiasm for "rescu[ing] troubled emerging economies" with public resources and imposing some portion of the costs of unsustainable sovereign debt on the sovereign lenders who had extended the credit in the first instance. ${ }^{7}$ But this support was not widely backed within the Department and, indeed, quickly evaporated as the IMF's report went public. ${ }^{8}$ By 2003, the IMF Board of Directors had rejected the SDRM proposal. ${ }^{9}$

The Board's rejection of the SDRM proposal did not resolve this policy debate for long. Within a few years, mortgage foreclosures grew at unexpected rates in the United States, which caused a U.S. financial crisis to trigger financial crises in Europe and elsewhere around the

4. See generally Ross P. BUCKLEy, InTERnational FinanCial System: Policy AND REGULATION 141 (2009) (noting that among the reasons there is no global sovereign bankruptcy regime is that creditors, while accepting domestic bankruptcy regimes, "have argued vociferously against a bankruptcy regime internationally ...”).

5. See, e.g., GrP. OF 30 [G-30], KeY Issues in Sovereign DeBT RESTRUCtuRING: A WORKING GROUP REPORT 9 (2002), available at http://www.group30.org/images/ PDF/ReportPDFs/sov_debt.pdf.

6. See Brad Setser, The Political Economy of the SDRM, in OVERCOMING DEVELOPING COUNTRY DEBT CRISES 318 (Barry Herman et al. eds., 2010) (listing the political constraints that shaped the IMF"s sovereign debt-restructuring mechanism: stakeholders had different views vis-à-vis the proper function of a sovereign bankruptcy regime; stakeholders for emerging market debt believed they were only indirectly concerned; and the IMF had to address the stakeholders' expectations while building consensus for change).

7. Id. at 318 .

8. See id.

9. Int'l Monetary Fund [IMF], IMF Surveillance in Action, Annual Report 2003, at 31-4 (2003), http://www.imf.org/external/pubs/ft/ar/2003/eng/pdf/file2.pdf. See also Aram Ziai, The Rise and Fall of the SDRM Proposal in the IMF: An Introduction to Competing Theoretical Perspectives on Power in the Global Political Economy, 6 \& 7 HAMBURG ReV. Soc. SCI. 1, 2 (2012), available at http://www.hamburg-review.com/fileadmin/pdf/06_03. 07_01/Ziai_SDRM.pdf. 
globe. ${ }^{10}$ The Global Financial Crisis resulted in more than several sovereign borrowers' defaults and has, in turn, renewed calls for revision of the process for restructuring sovereign indebtedness. ${ }^{11}$

This time, however, the rhetoric surrounding sovereign lending practices has shifted somewhat. Rather than comparing sovereign borrowers to corporations in financial distress, during the current global crisis many have referred to sovereign debt in terms comparable to household borrowing. When lending to sovereign borrowers who are facing national financial crises, the IMF and its European counterparts (referred to colloquially as the Troika) wanted assurances that repayment of sovereign loans would be sustainable. ${ }^{12}$ They argued that countries had overborrowed ${ }^{13}$ and should practice financial austerity ${ }^{14}$ as a means of paying down excessive sovereign debt. Like families with too much credit card debt, sovereign borrowers should address the problem by learning to live within a budget.

But this commitment to find sustainable sovereign debt levels through policies of austerity faltered. Efforts to prop up Greek sovereign debt proved insufficient; the notion that Greek austerity would render its sovereign borrowing sustainable proved untenable. By 2012, the IMF insisted on a restructuring of Greek sovereign bonds as a condition to access to further rescue; private bondholders accepted changed terms in the face of changed circumstances. ${ }^{15}$ In 2013, the IMF conditioned assistance to Cyprus on "bail-in" from uninsured depositors in systemically important Cypriot banks. ${ }^{16}$ With a new political party in

10. See, e.g., Block-Lieb \& Halliday, supra note 2, at 15-16 (explaining the origin of the Global Financial Crisis as beginning with mortgage-backed securities from 2000 to 2007 and spreading to Europe by 2008).

11. See infra text accompanying notes 173-199.

12. See JAMES Boughton ET AL, CTR. FOR INT'L GOVERNANCE INNOVATION, IMF LENDING PRACTICES AND SOVEREIGN DEBT RESTRUCTURING 5 (2014), https://www. cigionline.org/sites/default/files/cigi_pb_41.pdf (mentioning that in order for a country to qualify for relatively large loan amounts relative to the country's quota, the IMF wanted there to be a high probability of sustainability in the medium term).

13. See generally LEE C. BUCHHEIT ET AL., BROOKINGS INST., COMM. ON INT'L ECON. Policy \& REForm, REvisiting SOVEREIGN BANKRUPTCY (2013) [hereinafter BRoOKINGS REPORT] (discussing sovereign debtors' incentives to overborrow), http://www.brookings. edu/ /media/research/files/reports/2013/10/sovereign\%20bankruptcy/ciepr_2013_revisiting sovereignbankruptcyreport.pdf.

14. See, e.g., Stimulus v Austerity: Sovereign Doubts, THE ECONOMIST, Sept. 28, 2013, http://www.economist.com/news/schools-brief/21586802-fourth-our-series-articles-

financial-crisis-looks-surge-public (noting that Greece could not delay austerity measures since it could no longer finance its deficits).

15. See Jeromin Zettelmeyer et al., Greek Debt Restructuring: An Autopsy, 28 EcoN. POL'Y 513, 518, 526 (2013).

16. Stavros A. Zenios, The Cyprus Debt: Perfect Crisis and a Way Forward, 7 CYPRUS ECON. POL'Y REV. 3, 41 (2013). 
power by late 2014, Greece renewed demands to restructure this debt and loosen austerity requirements, including demands to restructure debt owed by it to the "lenders of last resort"- the IMF and European Central Bank (ECB). ${ }^{17}$ By July 2015, Greece had defaulted on its obligations to the IMF and was likely to default on debt owed to the ECB. ${ }^{18}$ A popular referendum, quickly called by Greek leadership, returned an unexpected "no" vote to further demands for austerity from the Troika, leaving negotiations on the terms of further lending (and any possible restructuring of existing debt) up in the air. ${ }^{19}$

Since 2013, the international community has begun to revisit questions regarding its approach to requests for sovereign lending in times of crisis. Several reports by IMF staff to its Board, including one in $2013^{20}$ and another in 2014, ${ }^{21}$ carefully compare various methods for resolving sovereign debt problems, including fresh consideration of debate on best practices for sovereign debt lending and debt restructuring. Concluding that sovereign debt restructurings often come "too late" and involve "too little" assistance to promote full recovery, ${ }^{22}$ IMF staff members have proposed a variation on the IMF's earlier SDRM proposal. Rather than bind dissenting holdouts to a full blown sovereign debt restructuring, they propose a "reprofiling" of some of this debt-a term meant to indicate an extension of bond due dates but no other amendments to the terms of the reprofiled sovereign debt-but

17. See Peter Eavis, Jack Ewing, \& Landon Thomas Jr., IMF and Central Bank Loom Large Over Greece's Debt Talks, N.Y. TIMES: DEALB\%K (May 10, 2015), http://www. nytimes.com/2015/05/11/business/dealbook/imf-and-central-bank-loom-large-over-greecesdebt-talks.html?_r=0.

18. See Gabriele Steinhauser et al., Greece Defaults on IMF Loan Despite New Push for Bailout Aid: European Finance Chiefs Shut Down Athens's Last-Minute Request for Emergency Financial Aid, WALL ST. J., July 1, 2015, 12:12 AM, http://www.wsj.com/ articles/some-greek-banks-to-open-for-pensioners-1435653433.

19. See Ian Traynor, John Hooper, and Helena Smith, Greek Referendum No Vote Signals Huge Challenge to Eurozone Leaders, THE GUARDIAN, July 5, 2015, 21:48, http://www.theguardian.com/business/2015/jul/05/greek-referendum-no-vote-signals-hugechallenge-to-eurozone-leaders; Douglas J. Elliott, Greece and Europe: This way to the exit? BROOKINGS UPFRONT (July 6, 2015 8: 28 am EST), http://www.brookings.edu/blogs/upfront/posts/2015/07/06-greece-and-europe-exit-eu-elliot?utm_campaign=Brookings+Brief\& utm_source=hs_email\&utm_medium=email\&utm_content=20396398\&_hsenc $=$ p2ANqtzZZvaHcc7gYU2EqOTgNla4bO6cxer1JSzPyJOUCIOtwbcV67AuH7dEVvO4wRuQ-Lvyw CVHTiKEDD49ULaVmL7ePV3V2T76pO2xCJJKvEAMPBIA72uc\&_hsmi=20396398.

20. IMF, Sovereign Debt Restructuring-Recent Developments and Implications for the Fund's Legal and Policy Framework 39 (Apr. 26, 2013) https://www.imf.org/external/np/ pp/eng/2013/042613.pdf [hereinafter 2013 Staff Report].

21. IMF, The Fund's Lending Framework and Sovereign Debt-Preliminary Considerations (June 2014), http://www.imf.org/external/pp/ppindex.aspx [hereinafter 2014 Staff Report] (discussing the implementation issues of reprofiling the IMF"s lending framework).

22. 2013 Staff Report, supra note 20 , para. 4 , at 7 . 
make clear that this reprofiling would occur purely as a matter of voluntary enforcement of contractual terms and not a statutorily imposed mandate. ${ }^{23}$

The self-organized Committee on International Economic Policy and Reform, writing under the aegis of the Brookings Institute, put forward its own report, in which it proposed three alternative mechanisms: one contractual, involving coordinated introduction of a strong form of collective action clauses; one statutory, involving legislation that immunizes "all payment and clearing systems in large financial centers"; and another IMF-based, involving a Sovereign Debt Adjustment Facility. ${ }^{24}$ The statutory proposal would condition lending from the IMF on the restructuring of unsustainable sovereign debt. ${ }^{25}$ The Committee premised its several proposals on the notion that some countries may overborrow ${ }^{26}$ and then wait too long to restructure their unsustainable debts. ${ }^{27}$

The characterization of sovereign debt relief as "too little, too late" sounds familiar to the ears of those attuned to debate in the United States on corporate insolvency reform. Corporate reorganization reform was urged in the 1970s on the grounds that companies should be encouraged not to wait to file until there was "nothing left to reorganize."28 This argument helped to shift concerns about the moral hazards of reforming corporate reorganization law in the United States in the mid-1970s. It may be hoped that similar arguments will shift similar fears about sovereign debt restructuring.

But is the case for sovereign debt restructuring or reprofiling best framed in terms reminiscent of debate on corporate insolvency reform? Or, is it instead better understood as a question about when sovereign debt becomes "unsustainable" and who should sit in judgment of these nations' economic sustainability - the debtor, some body of creditors, or an objective third party? This paper explores the differences between indebtedness owed by public and private - corporate, consumer, and sovereign-borrowers, and the implications of the restructuring of these distinct sorts of debt for different sorts of debtors' economic recoveries.

23. See 2014 Staff Report, supra note 21, paras. 12-15, at 11-12.

24. BROOKINGS REPORT, supra note 13 , at 29-34, 44-46.

25. Id.

26. Id. at 7-10. Although these sections refer explicitly to "overborrowing," one could also read the Brookings Report as referring to sovereign lenders' propensity to overlend. See id. at 8 ("Creditors, however, may have incentives to behave recklessly and lend without adequate regard to risk because official bailout packages may allow for repayments that are 'too high' with respect to the social optimum.").

27. Id. at 10-12.

28. See generally H.R. Doc. No. 93-137 (1973) (collecting reports on bankruptcy reform proposals). 
It concludes that there is much to learn from the comparison of sovereign to consumer debt.

Part I revisits the IMF's SDRM proposal in the wake of the Asian Financial Crisis and the failure of this proposal to command the needed international consensus. Support for the proposed SDRM was based on a comparison to U.S. corporate reorganization law; in the same way that binding dissenters to an agreement to restructure private debt approved by creditors is justified on utilitarian grounds, the SDRM proposal was described as promoting the common good.

Part II comments on the strength of this metaphor. Whatever the merits of an SDRM, this section distinguishes sovereign from corporate debt on the grounds that they present distinct obstacles to collection as well as distinct benefits from restructuring. It concludes that the metaphor to Chapter 11 corporate reorganization is imperfect but useful, especially in terms of offering a politically desirable framing of the issues at hand.

Part III turns to current events and current proposals for improvements in the process for sovereign debt restructuring. It argues that talk of countering questionably sustainable sovereign debt with austerity measures resembles the finger-wagging that overextended households often receive in the way of debt advice, and it questions whether restructuring of sovereign debts resembles the belt-tightening efforts that a family might pursue in similar circumstances.

Based on these distinctions, Part IV returns to the metaphor comparing sovereign debt to household debt and draws conclusions about renewed proposals for resolving sovereign debt problems. While the metaphor of sovereign debt to consumer debt may seem even more strained than the comparison of sovereign debt restructuring to corporate reorganization, this section argues that the shift in perspective explains much about sovereign debt and sovereign debt restructuring practices. Reframing sovereign debt problems as akin to consumer debt problems could renew interest in developing a framework for responsible sovereign lending and a fresh perspective on the goals and means for sovereign debt restructuring. ${ }^{29}$

29. See infra text accompanying notes 243-255. This paper is not the first to compare sovereign debt to consumer debt. See A. Mechele Dickerson, Insolvency Principles and the Odious Debt Doctrine: The Missing Link in the Debate, 70 LAW \& CONTEMP. PrOBS. 53, 6768 (2007); Robert K. Rasmussen, Integrating a Theory of the State into Sovereign Debt Restructuring, 53 EMORY L. J. 1159, 1180-84 (2004). Nor is it the first to recommend assessment of responsible sovereign lending practices. See, e.g., UNITED NATIONS Conference on Trade and Dev., Principles on Promoting Responsible Sovereign LENDING AND BorRowing (Jan. 10, 2012) [hereinafter UNCTAD PRINCIPLeS], http://unctadxiii.org/en/SessionDocument/gdsddf2012misc1_en.pdf. The UNCTAD 


\section{THE IMF's SDRM PRoposal IN THE WAKE OF THE ASIAN FINANCIAL CRISIS}

In the summer of 1997, a financial crisis in Thailand triggered similar problems throughout Southeast Asia. The Philippines, Malaysia, Singapore, and South Korea suffered currency devaluations, failures of banks and finance companies, and corporate financial distress. Financial institutions later failed in Hong Kong and Singapore as well, prompting financial failures in the then newly-constituted Russian Federation, in Brazil and Argentina, and in the United States in the form of the failure and bailout of Long-Term Capital Management. ${ }^{30}$ Stock markets roiled throughout the world; the Asian Financial Crisis threatened the world's economy. ${ }^{31}$

The Asian Financial Crisis demonstrated the interconnectedness of globalized financial markets-markets that were interconnected geographically, to be sure, but also connected across debt sectors, with capital flight prompting both bank and corporate failures. These financial failures prompted countries' intuitions to bail out companies and banks, which in turn prompted further capital flight, imbalances in currency and trade, and threats of default in sovereign debt markets. ${ }^{32}$

The international community responded to this threat with financial assistance. The IMF and World Bank extended loans to the Philippines, Thailand, Indonesia, and South Korea, but this financial assistance created market concern that these were "bailouts" that would promote "moral hazard" in lending markets-that is, excessive risk taking in future lending and borrowing decisions. ${ }^{33}$ In part to assuage these concerns, these international financial institutions (IFIs) attached strings to this crisis lending. As with similar loans that had been extended to Mexico and other countries several years earlier, the IMF conditioned these loans on sovereign borrowers' adoption of specific economic and legal reforms. ${ }^{34}$

Among the wide range of reforms encouraged through this policy of conditionality, the IMF and World Bank sought reform of corporate

\footnotetext{
Principles, which have garnered little interest in the international community, were not premised on a comparison of sovereign to consumer debt.

30. See, e.g., ANDREW Sheng, From Astan to Global Financial Crisis: AN ASIaN REGULATOR'S VIEW OF UNFETTERED FINANCE IN THE 1990S AND 2000S (2009).

31. Id.

32. $I d$.

33. Id. at 113 .

34. IMF, Recovery from the Asian Crisis and the Role of the IMF, § IV (June 2000), http://www.imf.org/external/np/exr/ib/2000/062300.htm\#I (noting that these "structural reforms" received greater prominence in the rescue packages extended during the Asian Financial Crisis than in "typical IMF programs").
} 
insolvency laws, including laws providing for "the establishment of viable workout mechanisms." 35 The need for financial-sector reforms was also viewed as "pressing," including, for example, efforts to strengthen "financial supervision and regulation." 36 In addition, the IMF encouraged "measures to increase transparency in the financial, corporate, and government sectors," "steps to improve the efficiency of markets and increase competition," and "efforts to shield poor and vulnerable sections of society from the worst of the crisis." 37

Although the IMF's policies of conditionality were controversial, legislatures in Korea, Indonesia, and elsewhere in Southeast Asia nonetheless adopted the recommended laws governing regulation of financial and capital markets, facilitating the restructuring of corporate indebtedness and mandating transparency in securities and other capital markets. ${ }^{38}$ The Asian Financial Crisis cooled quickly. By late 1999 , it had quieted; within several years, markets were viewed as having returned to normal. ${ }^{39}$

Economic recovery, however, did not dispel questions surrounding the wisdom of "bailing out" these emerging economies or the illegitimacy of the IFIs' conditional lending policies. In an effort to resolve this tension, finance ministers and central bank governors from twenty-two "systemically significant" economies met in April and again in October of 1998. Although in the past the leaders of the seven or eight largest industrialized democracies had met as a Group of Eight, it was agreed that reaction to the Asian Financial Crisis should also involve a larger and more inclusive club of nations. At the Asia-Pacific Economic Conference in 1997, U.S. President Bill Clinton and other Asia-Pacific Economic Corporation (APEC) leaders announced the formation of the G-22, which would focus specifically on matters of international finance. ${ }^{40}$

35. Id.

36. Id.

37. $I d$.

38. See, e.g., HALLIDAY \& CARRUTHERS, supra note 2, at 166-246.

39. See Timothy Geithner, President \& Chief Exec. Officer, Fed. Reserve Bank of N.Y., Reflections on the Asian Financial Crises (June 20, 2007) ("Recovery in the Asian crisis countries took time, but it was stronger and more rapid than had been typical in other emerging market financial crises. Barely 18 months after the crisis, for example, Korean GDP had returned to pre-crisis levels, and this was true for all the Asian crisis countries by 2003. .).

40. See IMF, Factsheet: A Guide to Committees, Groups, and Clubs 8 (Oct. 3, 2014), http://www.imf.org/external/np/exr/facts/groups.htm\#G22. 
The G-22 issued a lengthy Report on the International Financial Architecture at the first of two meetings. ${ }^{41}$ Through three separate working groups (transparency and accountability; strengthening financial systems; and international financial crises), the G-22 recommended a long list of structural reforms "related to the stability of the international financial system and the effective functioning of global capital markets." 42 These reports proposed revisions to prevent future financial crises, with each working group focused on a distinct aspect of this problem: the working group on transparency and accountability looked to ensure that balance sheets and other public records transparently revealed information to the markets; the working group on strengthening financial systems focused on financial institutions; and the working group on international financial crises tied the financial health of these entities to that of sovereign states more generally.

For example, proposals to enhance transparency and accountability included statements regarding consensus on the importance of private sector disclosure and the need for this information to be timely, complete, and consistently reported. ${ }^{43}$ The working group on enhancing transparency and accountability recommended international agreement on accounting standards and transparency on a broad range of financial and fiscal information reported by banks and corporations. ${ }^{44}$ The working group on strengthening financial systems endorsed adoption of existing principles on banking supervision and securities regulation; it encouraged the development of principles on corporate governance, internal controls, and deposit insurance. ${ }^{45}$ Proposals to strengthen international standards for corporate insolvency and collection laws were included among this long list of reforms. ${ }^{46}$

The working group on transparency and accountability emphasized the importance of reforming corporate insolvency laws. Nonperforming corporate loans might be hidden from market scrutiny, which could in turn inflate banks' balance sheets. Restructuring these nonperforming loans could clarify and improve financial conditions at both the corporate and bank levels. This structural reform might also have broader systemic effects. In addition, the working group on international financial crises identified "effective insolvency and debtor-

41. See IMF, Summary of Reports on the International Financial Architecture 1 (Oct. 1998), http://www.imf.org/external/np/g22/summry.pdf.

42. Id.; see also id. at 2-3.

43. See id. at 6.

44. See id. at 8-9.

45. See id at 11-13.

46. See id. at 13. 
creditor regimes" as important to "limiting financial crises and facilitating rapid and orderly workouts from excessive indebtedness"; 47 it linked recommendations on restructuring and reorganizing corporate over-indebtedness with that of public sector debt, stressing "the need to encourage better management of risk by the private and public sectors." 48 While it emphasized that "[c]ountries should make the strongest possible efforts to meet the terms and conditions of all debt contracts in full and on time" and cautioned that "[u]nilateral suspension of payments are inherently disruptive," the working group also set out a framework for promoting "the collective interest of [sovereign] debtors and creditors in cooperative and orderly debt workouts," 49 which included recommendations for expanded use of a range of "collective action clauses" in sovereign debt instruments, as well as official support for temporary suspensions in certain circumstances. ${ }^{50}$

In articulating the details of this framework, the G-22's financial crisis working group also explicitly drew a comparison between corporate and sovereign debt restructuring. Although noting that insolvency regimes can facilitate the orderly workout of corporate debt in a time of crisis, it conceded "[t]here is currently no analogous regime for sovereign debtors" and that the "creation of an internationally agreed and binding insolvency regime for sovereign debtors is unlikely." 51 It recommended inclusion of collective action clauses to enhance creditor coordination, while admitting that these "clauses are not likely to prove a panacea." 52 It provided guidance on the role of sovereign borrowers, the international community, and the private sector in this context, including discussion of "[m]echanisms to facilitate prompt and equitable workouts." 53

47. $I d$. at 3.

48. Id.

49. Id.

50. Id. at 20, 22. See also AMITA BATRA, INDIAN COUNCIL FOR RESEARCH ON INT'L ECON. RELATIONS, SOVEREIGN DEBT RESTRUCTURING (2002), http://www. icrier.org/pdf/OP02SovDebt.pdf (discussing approaches to sovereign debt restructuring in the aftermath of the emerging market financial crises of the late 1990s). The G-22 report was not the first report to recommend the including of Collective Action Clauses (CACs) in sovereign bonds. The Rey Report, issued by the G-10 in 1996, also had done so six years earlier. See BATRA, at 27.

51. Mervyn King et al., Bank for Int'l Settlements, Report of the Working Group on International Financial Crises 19 (Oct. 2, 1998), https://www.bis.org/publ/othp01d.pdf.

52. Id. at 20.

53. Id. at 33 ("Insolvency regimes generally provide a mechanism for the provision of new, senior credits to ensure the ongoing operation of the firm and the restructuring of existing debt. While the analogy to corporate insolvency is imprecise, working out international liquidity crises may also require mechanisms to encourage new capital 
Connecting corporate and sovereign debt restructuring was not simply a matter of intellectual purity for the G-22. It was widely understood that the Asian Financial Crisis had been triggered, in part, by over-indebted corporations in Indonesia and elsewhere. ${ }^{54}$ Because Chaebols accounted for a huge percentage of the balance sheets of Korea's largest banks-indeed, a significant portion of Korea's overall Gross National Product (GNP)—liquidation of these insolvent entities would have had systemic consequences. ${ }^{55}$ Commitments of financial support for Korean corporations and financial institutions caused markets to question the sustainability of sovereign indebtedness. The G22 's report was meant, in part, to quell these concerns. Its recommendation of Chapter 11-like corporate reorganization laws in Asia and elsewhere was an implicit criticism of national bailouts of these corporations.

The G-22 was concerned about more than the possibility of corporate bailouts; it was also concerned about the prospect of bailouts of sovereign debt. While the Asian Tigers subsequently repaid the rescue packages extended to them by the IMF, earlier experience with loans to Mexico and several South American countries made clear the political pressure for bailouts that could not be ignored.

The G-22's recommendations on sovereign debt emerged out of a rich academic debate on whether sovereign debt restructuring should be encouraged, and, if so, how this encouragement might best be structured. As early as 1981, commentators had argued that sovereign debt restructuring should be more closely patterned on U.S. Chapter 11 reorganization plans. ${ }^{56}$ While initially references to U.S. Chapter 11

inflows and supplementary frameworks to facilitate the orderly restructuring of existing debt.").

54. See, e.g., Steven Radelet \& Jeffrey Sachs, The Onset of the East Asian Financial Crisis, in CURRENCY CRISES 105, 114 (Paul Krugman ed., 2000), available at http://www. nber.org/chapters/c8691.pdf (noting that "in all countries except Korea, bank lending to nonbanks exceeded lending to banks").

55. Id.

56. See Benjamin J. Cohen, Essays in INT'L FIn., Princeton Univ,, DevelopingCoUNTRY DEBT: A MIDDLE WAY 3 (1989); JEFFREY SACHS, PRINCETON STUD. IN INT'L FIN., THEORETICAL ISSUES IN INTERNATIONAL BORROWING 38 (1984) (noting that in liquidity crises the credit market can overcome individual banks' tendency to squeeze credit by collectively forming loan agreements that guarantee debt rescheduling at below-market rates); Benjamin J. Cohen, A Global Chapter 11, 75 Foreign PoL'Y 109, 122 (1989); Christopher G. Oechsli, Procedural Guidelines for Renegotiating LDC Debt: An Analogy to Chapter 11 of the U.S. Bankruptcy Reform Act, 21 VA. J. INT'L L. 305, 308-09 (1981). See generally Kenneth Rogoff \& Jeromin Zettelmeyer, Early Ideas on Sovereign Bankruptcy Reorganization: A Survey (IMF, Working Paper No. WP02/57, 2002), available at http:// www.imf.org/external/pubs/ft/wp/2002/wp0257.pdf (surveying the history of sovereign debt restructuring mechanisms based on Chapter 11 bankruptcy principles). 
presented only a metaphor for orderly collative action, by the mid-1990s these proposals began to push on the comparison and propose mandatory statutory mechanisms for binding holdouts to a restructuring agreement. ${ }^{57}$ Later commentators questioned the need for a statutory resolution of this collective action problem, arguing that contractual provisions such as collective action clauses (CACs) through which bondholders agreed ex ante to be bound by a specified supermajority held important advantages. ${ }^{58}$ Rather than choosing sides in the debate, the G-22 report recommending inclusion of CACs in sovereign bond offerings assumed both the wisdom and the political difficulties of an international effort of this sort and looked to offer second-best proposals that were more likely to be implemented.

Shortly after the G-22's report on a new financial architecture, the IMF weighed in on some of the same issues. In 1999, its Office of Legal Counsel had published a short tract on "Orderly and Effective Insolvency Regimes," which fully supported and expanded on the G-22's recommendations regarding the desirability of a reorganization-friendly corporate insolvency regime. ${ }^{59}$ In a surprise to many, IMF senior staff

57. See BATRA, supra note 50 , at 5 (noting that by 1995 , "the proposals for sovereign debt restructuring had alternated between Oechsli's voluntary procedures and Cohen's statutory proposals," and that "there was at this time a suggestion towards a contractual approach to orderly debt resolution").

58. See, e.g., BARRY EICHENGREEN \& RICHARD PoRTES, CRISIS? What CRISIS? ORdERLY WORKOUTS FOR SOVEREIGN DEBTORS 49 (1995) (recommending "[c]hanges in bond covenants to permit a majority of creditors to alter the terms of payment").

59. See IMF Legal Dep't, Orderly \& Effective Insolvency Procedures, Foreword, Appendix, Part IV(B) (1999), http://www.imf.org/external/pubs/ft/orderly/. The IMF's report on corporate insolvency laws would be followed by the World Bank's Principles and Guidelines for Effective Insolvency and Creditor Rights Systems, see generally World Bank, Principles and Guidelines for Effective Insolvency and Creditor Rights Systems (Apr. 2001), http://www.worldbank.org/ifa/ipg_eng.pdf, revised by World Bank, 2011 Principles for Effective Insolvency and Creditor/Debtor Regimes (Jan. 20, 2011), available at http://siteresources.worldbank.org/INTGILD/Resources/ICR Principles_Jan2011.pdf (developing and later revising insolvency principles to guide system reform and benchmarking in developing countries), and UNCITRAL's Legislative Guide on Insolvency Law, see generally UN's Comm'n on Int'l Trade Law, Legislative Guide on Insolvency Law (2005) [hereinafter UNCITRAL, Legislative Guide on Insolvency Law], http://www. uncitral.org/pdf/english/texts/insolven/05-80722_Ebook.pdf (designing key objectives and provisions for effective insolvency law). Together these reports are understood to set international standards for corporate insolvency law. See, e.g., World Bank, Principles for Effective Creditor Rights and Insolvency Systems, GLOBal InsolvenCy LaW DaTaBaSe, http://web.worldbank.org/WBSITE/EXTERNAL/TOPICS/

EXTLAWJUSTICE/EXTGILD/0,, contentMDK:22095859 menuPK:64874173 pagePK:478 9622 piPK:64873779 theSitePK:5807555,00.html ("The 2011 Principles have been reviewed and revised to incorporate updates to UNCITRAL's Legislative Guide on Insolvency Law. In this regard, two new Principles (C16 and C17) have been added to reflect the best International Practice concerning the insolvency of Enterprise Groups.'). 
subsequently expressed their views on practices for addressing sovereign loans during times of crisis. ${ }^{60}$ Anne Krueger, the IMF's First Deputy Managing Director, addressed the National Economists' Club in Washington, D.C. in 2001 and proposed the establishment of an SDRM under the auspices of the IMF on the grounds that voluntary measures alone were insufficient. ${ }^{61}$ By mid-2002, Krueger published an IMF tract, titled "A New Approach to Sovereign Debt Restructuring," in which she laid out in greater detail her SDRM proposal.62

Although this timeline paints Krueger's SDRM proposal in the context of the Asian Financial Crisis and the G-22's report calling for a new financial architecture, the connections here are less clear-cut. At the height of this Crisis, the IMF had extended significant lending assistance to several of the Asian Tigers, but these sovereign loans were not at risk by 2001 and 2002.63 What, then, had prompted the IMF's SDRM proposal in 2001? Commentators argue that, more likely, Krueger and her legal staff were focused on the possibility of sovereign default elsewhere around the globe, such as Argentina. ${ }^{64}$ The fact that the G-22 had promulgated its report on sovereign debt in the context of the Asian Financial Crisis and as a result had linked issues of corporate and sovereign debt restructuring as logically connected, were points of reference less salient to the IMF proposal. Krueger, however, left the distinction between this Crisis and future possible crises unclear when putting forward her SDRM proposal. At most, Krueger and her team supported the case for an SDRM as important to "both crisis prevention and crisis resolution." 65

60. See, e.g., Ziai, supra note 9 , at 2 .

61. See Anne Krueger, First Deputy Managing Director, Int'l Monetary Fund, International Financial Architecture for 2002: A New Approach to Sovereign Debt Restructuring, at Part IV (Nov. 26, 2001), http://www.imf.org/external/np/speeches/ 2001/112601.htm (reproducing Krueger's speech given at the National Economists' Club Annual Members' Dinner at the American Enterprise Institute, Washington D.C.).

62. See generally KRUEGER, supra note 1 (outlining the broad features of Krueger's SDRM proposal).

63. See, e.g., Setser, supra note 6 , at 318 n.4.

64. Id. at 317 .

65. Anne O. Krueger, First Deputy Managing Director, IMF, Sovereign Debt Restructuring Mechanism - One Year Later, at Part II (Dec. 10, 2002), http:/www.imf.org/external/np/speeches/2002/121002.htm (reproducing Krueger's speech presented at the European Commission in Brussels, Belgium). Krueger went on in this speech to elaborate that the SDRM and other proposals to reform resolving sovereign debt restructuring practices "would contribute to crisis prevention because private markets would lend less to countries with already high debt-to-GDP ratios" and "would make crisis resolution more orderly and less costly, by providing incentives for countries to face up to their problems promptly." Id. 
Building on earlier commentators' metaphors, Krueger compared her proposed SDRM to a U.S. Chapter 11 reorganization proceeding. ${ }^{66}$ Although earlier commentators had differed on what they meant when they compared sovereign debt restructuring to corporate reorganization, Krueger identified four elements as critical to her proposal: (1) a stay of creditor enforcement during negotiations; (2) measures to protect creditors during the stay; (3) encouragement for new financing during proceedings; and (4) a mechanism to bind dissenters based on acceptance by a supermajority of similarly situated creditors. ${ }^{67}$ Recognizing that for an SDRM to bind dissenters it had to be supported by an international agreement of some sort, Krueger argued that the IMF was the best forum for the SDRM and, thus, that international agreement should occur through amendment to the IMF's Articles. ${ }^{68}$

There was little political support for an SDRM, however. Nearly as soon as Krueger made the SDRM proposal public, policy makers in the U.S. Department of the Treasury expressed their preference for contractual measures to address sovereign debt restructuring. ${ }^{69}$ The G22 had disbanded by 2000 , and was replaced by a slightly different G20. In its 1998 report, the G-22 had "forged consensus on a framework for debt restructuring ([centered on] collective action clauses and voluntary standards) and on the need for IMF quota reform,"70 but thereafter, the newly formed G-20 stepped back from exercising leadership on these issues. In its 2002 report, the G-20 hedged its bets and supported all extant proposals-it supported "work on comprehensive and market compatible approaches to crisis resolution, including CACs, a sovereign debt restructuring mechanism, and a code of good practices." 11 Nor was there much support for the SDRM proposal

66. See KRUEGER, supra note 1, at 10. Later in her proposal, Krueger also compares an SDRM to U.S. Chapter 9, governing municipal bankruptcy. See id. at 12-14.

67. $I d$. at 11. For a further elaboration of these principles, see $i d$. at 14-20.

68. See id. at 33-35.

69. John B. Taylor, Under Sec'y of the Treasury for Int'l Affairs, US Dep't of the Treasury, Sovereign Debt Restructuring: A US Perspective (April 2, 2002) available at http://www.iie.com/publications/papers/print.cfm?ResearchId=455\&doc=pub (reproducing remarks at the conference Sovereign Debt Workouts: Hopes and Hazards at the Institute for International Economics in Washington, D.C.). The U.S. response to Krueger's proposed SDRM was consistent with earlier statements by high-level officials in the Canadian government. See Batra, supra note 50, at 2.

70. Ngaire Woods, The G-20 Leaders and Global Governance 3 (Global Econ. Governance Programme, Global Economic Governance Programme, University College, Oxford, Working Paper No. 2010/59, Oct. 2010), available at http:/www.bruegel.org/ fileadmin/bruegel_files/Research_contributions/AEEF_contributions/G20_Completing_the _agenda/S1_N_Woods.pdf.

71. Leonardo Martinez-Diaz, The G-20 After Eight Years: How Effective a Vehicle for Developing-Country Influence? app. 2 at 29 (Brookings Inst., Global Econ. \& Dev., 
from the emerging economies. ${ }^{72}$ At around the same time as Krueger put forward her SDRM proposal, sovereign debt crises erupted in Argentina and Turkey, but both countries rejected loans from the IMF.73 Mostly, the SDRM affected sovereign contracting. If anything, "[t]he IMF's serious pursuit of an international bankruptcy regime ... contributed to Mexico's decision to introduce collection action clauses" in their bonds, a move that many viewed as undermining arguments that an SDRM was needed to ensure orderly collective action in this context. ${ }^{74}$

By 2003, the Board of Directors for the IMF voted to reject the SDRM proposal. ${ }^{75}$ With the IMF reluctant to amend its bylaws, the likelihood of the necessary international agreement on an SDRM diminished substantially, and the issue languished in the financial boom of the early twenty-first century.

\section{COMPARING SOVEREIGN BORROWERS TO A DEBTOR IN POSSESSION}

Whether public or private debt is at issue, all restructuring agreements suffer from the same basic problem: because they are purely contractual, multiparty restructuring agreements are enforceable only against those who agree to be bound. As such, incentives arise for some creditors to hold out strategically, even if the terms of the agreement otherwise make economic sense. Holdouts can demand full payment from the debtor. When only a few creditors hold out, this demand might be viewed as the price of getting the deal done. Depending on the number of the holdouts or the value of their claims, however, dissenters' demands for a premium can easily unravel a nascent restructuring agreement. Collective action problems, thus, complicate negotiation of a debt restructuring.

When Anne Krueger and earlier commentators pointed to U.S. Chapter 11 as a model for their SDRM proposals, they understood that a Chapter 11 plan of reorganization can enable socially beneficial restructurings to take place because it binds dissenting creditors-the holdouts mentioned above - to an agreement reached by a supermajority of the debtor's other creditors. Chapter 11 solves holdout problems by

Working Paper No. 12, Oct. 2007), available at http://www.brookings.edu/ /media/ research/files/papers/2007/10/17development/1017development.pdf.

72. See Setser, supra note 6, at 318, 338 n.4 ("Unlike the major Latin economies, most Asian economies hold so many reserves that they no longer worry about their ability to borrow from the IMF.").

73. Id.

74. Id. at 319.

75. Ziai, supra note 9 , at 2. 
creating a statutory mandate for dissenting creditors' participation in an agreement reached by a supermajority of creditors.

This statutory result comes at a price. When binding dissenters, Chapter 11 also looks to protect those creditors that would have been holdouts outside of the bankruptcy. ${ }^{76}$ It protects them both substantively and procedurally. Procedurally, Chapter 11 protects dissenters by mandating disclosure and good faith negotiation, ${ }^{77}$ by specifying how and when creditors' claims are classed together ${ }^{78}$ and how their votes are counted in assessing whether approval of a supermajority has been attained. ${ }^{79}$ It also institutes a system of checks and balances on the powers of a debtor in possession during the pendency of a case, such as through the appointment of a representative committee of creditors and through other means. ${ }^{80}$ Just as importantly, Chapter 11 protects dissenters substantively - for example, by requiring bankruptcy courts to assess whether the agreed-upon plan of reorganization is "feasible," 81 whether priority claims will be paid in full, ${ }^{82}$ and whether every creditor, including dissenters, will receive as much under the plan as they would have received in a liquidation of the debtor. ${ }^{83}$ Provisions permitting the confirmation of a prepackaged or prenegotiated plan of reorganization provide additional procedural protections for both supermajorities and their holdouts. ${ }^{84}$

76. Chapter 11 binds dissenters based on the agreement of a supermajority of the debtor's creditors, and on this ground has been referred to as resolving collective action problems. But resolution of hold-out problems should not be conflated with other ways in which bankruptcy law more generally resolves common pool problems. Especially where business debtors are concerned, a debtor's insolvency can prompt multiple defaults and multiple creditors pursuing simultaneous collection actions. Outside of bankruptcy, these creditors' race for the courthouse is understood to destroy value-and in particular to destroy the "going concern" value of an entity. Bankruptcy solves this collective action problem by means of an automatic stay aimed at protecting a debtor's operations and avoiding prepetition asset grabs. See generally Elizabeth Warren, Bankruptcy Policy, 54 U. CHI. L. REV. 775 (1987) (discussing the prototypes of default and the impact on creditors drawn into bankruptcy).

77. 11 U.S.C. $\$ 1125$ (2013).

78. See id. $\$ 1122$.

79. Id. $\S 1126(\mathrm{~d})$. Only the votes of impaired claims are counted, a concept defined in section 1124 of the Code. See id. $\$ 1124$.

80. The Code requires formation of an Official Committee of Unsecured Creditors, except in a small business cases. See id. $\S \S 1102-1103$. Although generally a debtor remains in possession of property of the estate and exercises the powers of a trustee in bankruptcy, see id. $\S \S 1107-1108$, a trustee might be appointed for cause. See id. $\S \S 1104-$ 1105.

81. Id. $\S 1129(\mathrm{a})(11)$; S. REP. No. 95-989, at 128 (1978).

82. 11 U.S.C. § 1129(a)(9) (2013).

83. Id. $\S 1129(\mathrm{a})(7)(\mathrm{A})(\mathrm{ii})$.

84. Id. $\S 1129$ (a). 
These procedural and substantive protections for dissenters measure the fairness of a proposed plan of reorganization against what creditors would have received if the debtor's assets were sold quickly and the proceeds distributed to its creditors on a pro rata basis. But a sovereign debtor's assets mostly defy liquidation. And sovereign debtors enjoy immunity from most litigation in most courts. As a result, the fairness of binding dissenters to the agreement of a supermajority of the debtor's other sovereign creditors cannot be measured against liquidation alternatives. In the absence of this comparison, an SDRM may be nothing like a Chapter 11 plan of reorganization. It may be nothing more than an effort to undermine some creditors' rights to payment in full.

Of course, Krueger and the commentators who preceded her understood that Chapter 11 was an imperfect metaphor for an SDRM. Krueger's report on the SDRM proposal admits as much, conceding that sovereign debtors differed from corporate debtors because a sovereign debtor's assets could not be liquidated; that sovereign creditors should not expect that an SDRM would provide for debt-to-equity conversions permitting extinguishment of "shareholders' ownership interests" in the debtor in the way that debt-to-equity swaps worked in corporate restructurings; and that it would be difficult to replicate in an SDRM context a similar system of Chapter 11-type checks and balances intended to safeguard the interests of creditors during the proceedings, especially nothing that might be viewed as a constraint on a sovereign debtor's fiscal powers. ${ }^{85}$ Nonetheless, comparisons of the SDRM proposal to U.S. Chapter 11 persisted, and continued to do so throughout extended debate on the proposal for reasons that transcended the fit between corporate and sovereign debt.

As noted above, the metaphor had passed through academic circles for some time, and was part of a larger debate on development policy. In the 1980s, economists had argued that developing nations' persistent problems of poverty were the result of their "debt overhang," thereby extending a basic insight of corporate finance to apply to the context of sovereign debt.86 In corporate contexts, "debt overhang" referred to the idea that high levels of indebtedness could stultify a firm by rendering it unable to borrow (or raise equity) to finance an otherwise profitable project because funders feared that the debtor might later be unable

85. KRUEGER, supra note 1, at 11-12.

86. See generally Ishac Diwan \& Dani Rodrik, Debt Reduction, Adjustment Lending, and Burden Sharing (Nat'l Bureau of Econ. Research, Working Paper No. 4007, 1992), available at http://www.nber.org/papers/w4007.pdf (analyzing the issue of debt overhang with reference to various economists who had weighed in on the debate). 
both to repay them and earlier lenders. ${ }^{87}$ Paul Krugman argued that sovereign debt overhang also limited growth, although he referred in this context to the effects of excessive sovereign debt on developing countries' economic growth; on this basis, Krugman argued that sovereign countries' debt overhang problems should be resolved, either through debt forgiveness or refinancing and restructuring of that debt. 88 Jeffrey Sachs similarly argued that developing countries' debt overhang limited their growth and would continue to have deleterious effects on development unless excess debt was forgiven. ${ }^{89}$ This idea quickly took hold in international circles, and by 1989 the IMF's World Economic Overlook purported to support this claim empirically. ${ }^{90}$

Not everyone agreed that developing countries' intractable poverty was the result of debt overhang or that it should be remedied through broad forgiveness or restructuring of sovereign debts. Economists at the Organization for Economic Co-operation and Development (OECD) published a report questioning the IMF's data analysis on the topic. ${ }^{91}$ Jeremy Bulow and Kenneth Rogoff also fervently opposed the ideas. ${ }^{92}$ Bulow and Rogoff argued that sovereign debtors differed from corporate ones and that resolution of their "debt overhang" should also be distinct. 93

Until the IMF proposed its SDRM, debate about whether sovereign debt did or did not create debt overhang problems and whether, like corporate debt overhang, these problems were better resolved through restructuring or forgiving this debt or by letting the market take its

87. See Stewart C. Myers, Determinants of Corporate Borrowing, 5 J. FIN. ECON. 147, 152-55 (1977). Corporate debt restructuring, whether the voluntary contractual sort or mandatory statutory sort like that found in Chapter 11, is understood to resolve the problem of debt overhang. See, e.g., Kenneth Ayotte \& David A. Skeel, Jr., Bankruptcy or Bailouts?, 35 J. CoRP. L. 469, 476 (2010).

88. See Paul Krugman, Financing vs. Forgiving a Debt Overhang, 29 J. Dev. Econ. 253, 254-55, 262-63 (1988). In another paper, Krugman argued that market based debt reductions measures were unlikely to work; because he understood there to be "no Chapter XI" for sovereign borrowers, Krugman viewed debt forgiveness as the better of the available options. See Paul R. Krugman, Market-Based Debt-Reduction Schemes 9-10 (Nat'l Bureau of Econ. Research, Working Paper No. 2587, 1988).

89. See, e.g., Jeffrey D. Sachs, Conditionality, Debt Relief, and the Developing Country Debt Crisis, in 1 Developing Country Debt and Econ. Performance, Volume 1: The INT'L FIN. SYSTEM 255, 257-258 (Jeffrey D. Sachs ed., 1989).

90. IMF, A Survey by the Staff of the International Monetary Fund, World Economic Outlook 52-54 (Apr. 1989).

91. See Bert Hofman \& Helmut Reisen, Debt Overhang, Liquidity Constraint and Adjustment Incentives 11-12 (Organisation for Econ. Co-Operation and Dev. Ctr., Working Paper No. 32, 1990).

92. See Jeremy Bulow \& Kenneth Rogoff, Cleaning Up Third World Debt Without Getting Taken to the Cleaners, 4 J. ECON. PERSP. 31, 35-36 (1990).

93. Id. 
course, had remained a debate about developing countries' sovereign debt obligations. Debate among Krugman, Sachs, and Bulow and Rogoff about sovereign debt and development policy had largely focused on the debt owed by poor and underdeveloped nations, but the Asian Financial Crisis had implicated developed nations like Korea and emerging economies like Malaysia. References to this debate in the G-22's report on lessons learned from the Asian Financial Crisis had shifted this conversation to one with a far broader application-the restructuring of sovereign debt owed, not just by the poorest nations, but also those countries whose indebtedness had grown as a consequence of the financial crisis. The list of applicable countries, and the amount of debt at stake, had substantially expanded with the G-22 report.

What had also shifted was an understanding that sovereign debt crises might have systemic implications. The Asian Financial Crisis had raised awareness of the interconnectedness of debt and financial distress and the systemic implications of these connections. Moreover, comparison of sovereign debt restructuring to corporate restructuring and reorganization served to emphasize this relationship.

Commentators had long understood that bank failures-that is, financial crises-might lead to unsustainable sovereign debt. To prevent a run on the bank, a nation might ex ante guarantee depositors' claims up to some maximum or ex post bail out a teetering bank. Whether ex ante or ex post, commitments to save domestic financial institutions might strain public coffers, creating in turn a sovereign debt crisis.

The G-22's report also connected corporate insolvency to bank insolvency. If a large portion of the commercial loans held on the balance sheet of a systemically important bank were uncollectable, these nonperforming loans (NPLs) might in turn trigger insecurity about the bank's solvency. In part, the G-22, various IFIs, and the UN's Commission on International Trade Law (UNCITRAL) sought to promulgate international standards on corporate insolvency law as a way to prevent corporate debt problems from creating a financial crisis. ${ }^{94}$ In doing so, they pointed to U.S. Chapter 11 as an exemplary model. Why then should Chapter 11 not also serve as a model for international standards on resolution of sovereign debt problems?

Thus, the IMF's reliance on the metaphor of Chapter 11 can also partly be explained for its political resonance, but not in a straightforward sense. Politically, the debate about sovereign debt overhang had been marginalized somewhat in that, before the Asian Financial Crisis, sovereign debt restructuring had been viewed as a

94. See, e.g., HALlidAY \& CARRUTHERS, supra note 2; Block-Lieb \& Halliday, supra note 2 . 
"developing country problem" that only peripherally involved the largest economies. But this view changed with the Asian Financial Crisis. The speed with which the Crisis had unfolded surprised many; the breadth of the interconnectedness of financial markets it revealed meant that, as painful as the Asian Financial Crisis had been, it could have been far worse. That policy makers felt the need to react to the Crisis through an expanded network of financial regulators-a G-22 and not simply a G7-and that this network of experts focused so immediately on preventing "the next crisis" suggests that conversation about sovereign debt restructuring was no longer considered to be just a "developing country problem."

Discussion of the systemic implications of sovereign indebtedness (or, indeed, of corporate or other sorts of debt) was tempered by framing this conversation in terms of the economic and financial implications of debt overhang. The language was dry, the symbolism mathematic. Economists at the various IFIs would immediately appreciate the implications of this reference, but few others shared this understanding. Extending the metaphor to compare the proposed SDRM to Chapter 11 corporate reorganization also extended the scope of the audience to whom this proposal was directed. Now lawyers, and particularly elite lawyers engaged in a global cross-border insolvency practice, were in on the debate.

The logic that connected corporate and sovereign debt restructuring also benefited this debate on an SDRM because, by the time Krueger's report on the SDRM was published, enormous progress had been made on a broad-based agreement on international standards for corporate insolvency reform. By 1999, the IMF's legal team had fleshed out the contours of the G-22 proposal with its tract on "Orderly \& Effective Insolvency Systems." 95 By 2001, the World Bank had released an initial draft of its "Principles and Guidelines for Effective Insolvency and Creditor Rights System."96 When Krueger's report was published, UNCITRAL was adding the final touches to what would become its Legislative Guide on Insolvency Law. ${ }^{97}$ Implicitly, if corporate

95. See IMF Legal Dep't, supra note 59.

96. The World Bank, Principles and Guidelines for Effective Insolvency and Creditor Rights Systems (Apr. 2001), available at http://www.worldbank.org/ifa/ipg_eng.pdf. By 2005, the World Bank had revised its first draft of these Principles and Guidelines. See The World Bank, Principles for Effective Insolvency and Creditor Rights Systems (2005), available at http://siteresources.worldbank.org/GILD/Resources/FINAL-ICRPrinciplesMarch2009.pdf (revising the 2001 principles based on experience and feedback from the World Bank's international partner organizations).

97. UNCITRAL, Legislative Guide on Insolvency Law, supra note 59. Indeed, Krueger's discussion of the proposed SDRM referred to these international texts as having set 
restructurings modeled on U.S. Chapter 11 presented international standards on the resolution of unsustainable corporate debt, so too might these laws also serve as a model for the restructuring of unsustainable sovereign debt. If UNCITRAL and other international organizations could succeed in drafting international standards in the corporate context, an international solution for sovereign debt restructuring seemed more plausible.

Reference to corporate reorganization law as a model for sovereign debt restructuring was also politically appealing because the case for corporate rescue and restructuring often is painted as win-win situation. A Chapter 11 plan of reorganization is only confirmed if the court agrees that it is in the "best interest of creditors"-that is, if no objecting creditor would have been better off in the event of the debtor's liquidation..$^{98}$ The notion is that creditors are no worse off as a result of the confirmed plan of reorganization, and might even be better off-the "pie" might get bigger-since the debtor might be willing to share with its creditors a portion of the benefits it receives from remaining in operation post confirmation..$^{99}$

As a result, the case for corporate restructuring is not a distributional one. Creditors may object to the delay and administrative expense of a Chapter 11 case, but in theory at least they should have no basis for complaining that reorganization is financed on the backs of the debtor's (unsecured or secured) creditors. Not only do these same creditors "do no worse" as a result of the delay, in that they receive no less than they would have in a liquidation scenario, arguably they should also "do better" in that any excess above liquidation value they receive comes out of a going concern value that belongs to the debtor and not the creditors. 100

A similar rhetoric framed the case for SDRM. In her speech before the European Commission in 2002, Krueger argued that sovereign creditors would receive more under an SDRM than they otherwise would have. ${ }^{101}$ Because holdouts may unravel a sovereign debt

international standards on the topic of corporate reorganization law. See KRUEGER, supra note 1 , at $12-13$

98. For codification of best interest of creditors standard, see 11 U.S.C. $\S 1129(a)(7)$ (2013).

99. See, e.g., Ronald J. Mann, Bankruptcy and the Entitlements of the Government: Whose Money Is It Anyway? 70 N.Y.U. L. REV. 993, 1005-06 (1995).

100. Id.

101. See Krueger, supra note 65, at Part V ("At present, the threat of a disorderly workout means that the value of creditor claims falls more sharply on the secondary market when a country gets into trouble than it would likely do in a more predictable environment. A framework that allows creditors to preserve better the value of their 
restructuring, Krueger argued that an SDRM's restraint of dissenting holdouts would maximize social welfare. 102

But this argument misses the point, to some degree. In the context of a Chapter 11 reorganization, every creditor is guaranteed a distribution that is no worse than what it is otherwise legally entitled to recover. On this basis, Chapter 11 is described as win-win situation. But sovereign creditors could not receive a similar assurance under an SDRM. Moreover, sovereign debtors cannot promise their lenders a share of their going concern valuation since this differential is unlikely to exist in a sovereign setting. Each sovereign creditor is legally entitled to payment in full, and an SDRM would enforce some lesser recovery. Viewed from this perspective, an SDRM held distributional consequences absent in a corporate reorganization.

There was another set of distributional consequences hovering in the background of the SDRM debate: IMF bailouts had frustrated many, both in the U.S. Department of the Treasury and within the IMF leadership. ${ }^{103}$ IMF bailouts were viewed as problematic not just because they might create moral hazard problems for both sovereign borrowers (who delayed proposing a resolution to sovereign debt problems in the hope that the IMF would bail out) and sovereign creditors (who held out from agreeing to a proposed restructuring in the hope of a bailout), but also because a bailout shifted costs onto the shoulders of the IMF's creditor countries-those countries whose contributions to the IMF are available for distribution. Critics of IMF bailouts "saw an international bankruptcy regime that would provide sovereigns with additional legal protection during a debt restructuring as an alternative to big IMF bailouts" and, thus, "as a means to scale back large IMF rescue loans and to force the IMF to return to its traditional lending limits."104 Comparing the SDRM to a U.S. Chapter 11 reorganization hid, to some extent, debate on the distributional implications of a bailout. Bailouts were not on the corporate reorganization radar screen.

Thus, the metaphor of a failing corporation proved to be powerful, but not powerful enough to rebut claims that a statutory (that is, a mandatory) SDRM presented an unnecessary intrusion on national sovereignty when contractual means were likely to resolve the collective action problems that inhered in sovereign debt restructuring. These clauses would not bind creditors covered by bonds that did not have such clauses, but the sovereign debt market had by 2003 settled into a

claims and debtors to minimize output losses during the restructuring period helps both creditors and debtors.").

102. KRUEGER, supra note 1 , at 8 .

103. Radelet \& Sachs, supra note 54, at 142-49.

104. Setser, supra note 6 , at 319 . 
groove that seemed to accept the status quo as good enough. ${ }^{105}$ Nevertheless, this sanguine perspective would last only several years.

\section{REVISITING SOVEREIGN DEBT RESTRUCTURING AS THE CURRENT GLobal FinANCIAL CRISIS RECEDES}

The Global Financial Crisis began in the United States in 2007 and 2008. As risky subprime mortgages defaulted at unexpected rates beginning in mid-2006 and 2007,106 U.S. subprime mortgage finance companies filed for bankruptcy, causing highly leveraged securitization arrangements to default and creating further uncertainties in markets for prime residential mortgages, in markets for all sorts of asset-back securities, and eventually in the liquidity of global capital markets more generally. Liquidity constraints emanating from the United States stressed systemically important members of global financial markets, including banks and nonbanks alike.

In early reaction to the current Global Financial Crisis, the U.S. Congress reluctantly agreed to ratify a Troubled Asset Relief Program (TARP) proposed first by the Bush administration and later by the Obama administration. The U.S. government provided emergency financial backing to some entities (a wide range of national banks, Fannie Mae and Freddie Mac, American International Group (AIG), General Motors (GM), and Chrysler), while others were pushed into private sales occurring inside (IndyMac, Lehman Brothers) and outside (Bear Stearns, Merrill Lynch, Countrywide Mortgage) the U.S. bankruptcy system. TARP funding was used to bolster some financial institutions (that is, national banks) and protect depositors (that is, bank creditors favored under the law) in the United States, as well as to bailout other systemically important financial and nonfinancial actors (like AIG, Chrysler and GM). But access to this funding was withheld from others (like Lehman). For those unable to obtain TARP funding (like Lehman), Chapter 11 offered some solace.

Debate on the wisdom of these bailouts, and whether bankruptcy (either liquidation or reorganization) of these entities should have been

105. See generally G-30, supra note 5 .

106. For discussion of the factors leading to understatement of the risks associated with securitized subprime residential mortgages, see generally Susan Block-Lieb \& Edward J. Janger, Demand-Side Gatekeepers in the Market for Home Loans, 82 TEMP. L. REV. 465 (2009) (discussing agency problems in the market for securitized home loans and the resulting need for consumer protection and consumer education to protect the integrity of the market). 
preferred, divided lawmakers and pundits. 107 Especially following midterm elections in the first term of the Obama administration, Republican lawmakers pushed against full implementation of TARP funding and toward increased austerity. 108

Banks and corporations were not the only actors left financially distressed in the wake of the Global Financial Crisis. The crisis had begun as a foreclosure crisis in the United States, and as a result, defaulting borrowers often found themselves enmeshed in foreclosure actions in one of fifty state courts. While some argued that U.S. bankruptcy law should be amended to permit modification of residential mortgage terms in the context of a Chapter 13 debt-repayment plan, Congress was convinced that banks' wholesale "marking to market" of residential mortgage would trigger greater financial crisis. ${ }^{109}$ Instead, the U.S. government put in place monetary incentives for certain banks to modify residential mortgages voluntarily through the Home Affordable Modification Program (HAMP) and the Home Affordable Refinance Program (HARP), but banks' disinterest in refinancing underwater mortgages meant that the success of these programs grew only slowly. ${ }^{110}$ Foreclosures lingered in state courts for years. As a result, many U.S. homeowners' residential mortgages were neither bailed out with TARP money nor restructured with HAMP money.

Failures within the financial services industries leapt from the United States to the United Kingdom to Iceland and back to the United States. In this context, too, bank failure caused and was caused by household debt problems. The failure of the U.K. bank, Northern Rock, caused financial turmoil within Icelandic banks. Within Iceland, bank failures triggered a financial crisis and currency imbalance, which triggered defaults in residential mortgages and other consumer debts. ${ }^{111}$

107. See generally Ayotte \& Skeel, supra note 87 (discussing the debate between bankruptcy and government-orchestrated rescue systems).

108. Sharon Otterman, Republicans Are Resistant to Obama's Stimulus Plan, N.Y. TIMES, Jan. 25, 2009, http://www.nytimes.com/2009/01/26/us/politics/26talkshow.html?_r=0.

109. For discussion of Dodd-Frank and its legislative history, see Susan Block-Lieb \& Edward J. Janger, Reforming Regulation in the Markets for Home Loans, 38 FORDHAM URB. L.J. 681, 698-99 (2011).

110. See, e.g., Timothy F. Geithner, Stress Test: Reflections on Financial Crises 302, 376 (2014); see also Jean Braucher, Humpty Dumpty and the Foreclosure Crisis: Lessons from the Lackluster First Year of the Home Affordable Modification Program (HAMP), 52 ARIZ. L. REV. 727, 752, 786 (2010); see also Alan M. White \& Carolina Reid, Saving Homes? Bankruptcies and Loan Modifications in the Foreclosure Crisis, 65 FLA. L. REV. 1713, 1719, 1726-27 (2013).

111. See, e.g., Nathaniel Popper, After Crisis, Iceland Holds a Tight Grip on Its Banks, N.Y. TIMES: DEALB\%K (Jan. 15, 2014, 6:47 PM), http://dealbook.nytimes.com/2014/01/15/ after-crisis-iceland-holds-a-tight-grip-on-its-banks/. 
Never before had consumer credit assumed systemic consequences, but Iceland's household debt problems were both caused by their financial and sovereign debt crises and further hampered resolving either. Icelandic household debts had been pegged in currencies other than the Icelandic kroner-Euro, Yen, and U.S. dollars-because Icelandic banks had hoped to match these loans with the currency denomination of deposit accounts. ${ }^{112}$ When Iceland's balance of payments roiled in reaction to bank failures in those currencies' countries, Icelandic consumers were pulled into a vortex of North Atlantic financial troubles. This meant that much Icelandic mortgage debt and consumer credit constituted NPLs on Icelandic banks' balance sheets, which in turn made Icelandic banks' financial crises difficult to resolve without resolution of this household debt problem.

When the G-20 met in Washington, D.C. in November 2008 "amid serious challenges to the world economy and financial markets," 113 the Global Financial Crisis had just begun, leaving this newly reconfigured Club of Nations somewhat flatfooted. Despite the threat to global financial markets, the G-20's message did not alter much from earlier meetings. At its meeting in the fall of 2008, the G-20 leaders pledged "closer macroeconomic cooperation, to restore growth, avoid negative spillovers and support emerging market economics and developing countries," but also, as with its earlier efforts to enhance the global financial architecture, the G-20 committed to "strengthen[ing] financial markets and regulatory regimes so as to avoid future crises." 114 Like similar commitments made following the Asian Financial Crisis, the G20 committed to a strengthening of financial market transparency, "including by enhancing required disclosure on complex financial products and ensuring complete and accurate disclosure by firms of their financial conditions," 115 and a strengthening of "regulatory regimes, prudential oversight, and risk management."116 It also

112. See, e.g., Jochen R. Andritzky, Resolving Residential Mortgage Distress: Time to Modify? 5 (IMF, Working Paper No. WP/14/226, 2014) ("A 50 percent devaluation of the [Icelandic] krona in 2008 was followed by many household loan defaults, particularly of CPI indexed or foreign currency linked mortgages.").

113. Grp. of Twenty [G-20], Declaration of the Summit on Financial Markets and the World Economy, para. 1 (Nov. 15, 2008), available at http://www.un.org/ga/president/63/ commission/declarationG20.pdf. The G-20 had met between 1999 and 2007, but these interim meetings were sideshows to the G-8 summits, merely opportunities for central bankers and financial regulators from the 22 largest economies to assess progress that the Financial Stability Forum had achieved on the Global Financial Architecture project. When the G-20 met in 2008, the group had changed. This time, unlike earlier meetings, the leaders of the 20 largest economies met.

114. Id. at paras. $7-8$.

115. Id. at para. 9 .

116. Id. 
committed to promote integrity in financial markets "by bolstering investor and consumer protection."117 Unlike its silence on the topic in 1998, the G-20 also proposed reforms of the Bretton Woods Institutions and in the Financial Stability Forum so that emerging and developing countries would hold greater voice and representation in these entities. ${ }^{118}$ Most reminiscent of the G-22's report in 1998, the G-20 committed in 2008 to an "action plan" that closely resembled its earlier financial architecture plan. It proposed structural reforms on seven issue areas. ${ }^{119}$

However, the G-20 said little to nothing in this 2008 report on the need for structural reform of insolvency laws, and was completely silent on whether international standards on the modification of residential mortgages or otherwise could resolve consumers' over-indebtedness. ${ }^{120}$ In addition, the G-20 was silent on the issue of sovereign debt restructuring at early stages of the Global Financial Crisis. In 2008 and early 2009 , the view was that this was largely a financial and not a sovereign debt crisis, ${ }^{121}$ a view altered within the year. Just as the G20's 2009 meeting was getting under way, the Greek government

117. Id.

118. Id. By 2009, the G-20 reports emphasized the need to reconstitute and restructure the Financial Stability Forum (FSF) as a more permanent Financial Stability Board (FSB). G-20, The Global Plan for Recovery and Reform, para. 14 (Apr. 2, 2009). It issued a declaration, entitled "Strengthening the Financial System," which pledged to establish a new Financial Stability Board composed of "all G20 countries, FSF members, Spain and the European Commission" and tasked the IMF to collaborate with the FSB to "provide early warning of macroeconomic and financial risks and the actions needed to address them." Id. at para. 15.

119. G-20, Declaration of the Summit on Financial Markets and the World Economy, supra note 113, para. following para. 16 (strengthening transparency and accountability, enhancing sound regulation, prudential oversight, risk management, promoting integrity in financial matters, reinforcing international cooperation, and reforming international financial institutions).

120. Whereas reform of corporate insolvency and creditor-debtor regimes had in the past figured prominently in the project to strengthen the global financial architecture, there was virtually no mention of bankruptcy within the 2008 report of the G-20. See id. (providing that, within medium-term actions relating to enhancing of sound regulation, "national and regional authorities should review resolution regimes and bankruptcy laws in light of recent experience to ensure that they permit an orderly wind-down of large complex cross-border financial institutions"); see also Block-Lieb \& Halliday, supra note 2, at 17 .

121. See Block-Lieb \& Halliday, supra note 2, at 18. To be sure, Iceland sought rescue funding from the IMF in November 2008, but the IMF had succeeded in quickly injecting funds there, thus cordoning off Iceland's default from the rest of world. See id. On the relationship between financial crises and sovereign debt crises, see generally Christoph G. Paulus, The Interrelationship of Sovereign Debt and Distressed Banks: A European Perspective, 49 TEX. INT'L L.J. 201 (2014). 
announced enormous budget deficits. ${ }^{122}$ Although this announcement did not itself constitute a default under the terms of its sovereign debt, the deficits nonetheless exceeded permissible levels specified under standards set by the European Union. ${ }^{123}$

By the time of the G-20's 2009 meeting in London, the G-20 countries agreed to an "unprecedented and concerted fiscal expansion" of five trillion dollars. ${ }^{124}$ The United States was not alone in providing monetary assistance to systemically important financial entities-the European Central Bank, the U.S. Federal Reserve System, the Bank of England, and the Central Banks for Australia, Canada, Japan and others all injected money into the global financial system early in the crisis. ${ }^{125}$ But this was not to be a long-lasting commitment to public debt as a means of averting global economic depression. When Greece later looked to the European Union for continued financial support, these requests were met with demands that the Greek government contain its crisis through greater austerity. Riots broke out in the streets of Athens.

Although in 2009 Greece's sovereign debt problems may have felt predominantly like European problems and not a fully "global" financial crisis, the severity of Greece's financial problems and the full extent of the interconnectedness of Greece with European and, indeed, global financial markets quickly revealed themselves. Greek sovereign debt ratings decreased in the spring of 2010 to "junk bond" levels, which created fears that Greece would default on its debts. ${ }^{126}$ The depth and breadth of European banks' Greek debt holdings caused markets to speculate on the extent to which a Greek default might create a wider European crisis. ${ }^{127}$ Spain's sovereign debt ratings were downgraded in the spring of 2010.128

By May 2010, the IMF, European Central Bank, and European Commission jointly announced a $\$ 146$ billion rescue package containing

122. David Jolly, 2009 Greek Deficit Revised Higher, N.Y. TIMES, Nov. 15, 2010, http://www.nytimes.com/2010/11/16/business/global/16deficit.html.

123. See Block-Lieb \& Halliday, supra note 2, at 18. Moreover, Greece's sovereign debt ratings fell as a result of this announcement. See $i d$.

124. G-20, London Summit - Leaders' Statement, para. 6 (Apr. 2, 2009), available at http://www.imf.org/external/np/sec/pr/2009/pdf/g20_040209.pdf.

125. See IMF, Global Economic Policies and Prospects, Group of 20 Meeting of the Ministers and Central Bank Governors, March 13-14, 2009, London, U.K. (2009), available at $\mathrm{https://www.imf.org/external/np/g20/pdf/031909a.pdf.}$

126. Chavon Sutton, S\&P Downgrades Greek Debt to Junk Status, CNN MoNEY (Apr. 27, 2010, 1:52 PM), http://money.cnn.com/2010/04/27/news/international/Greece_debt_ downgraded/.

127. Landon Thomas Jr., Europeans Fear Greek Debt Crisis Will Spread, N.Y. TIMES, Apr. 28, 2010, http://www.nytimes.com/2010/04/28/business/global/28euro.html?dbk.

128. Julianne Pepitone, Fitch Slashes Spain's Credit Rating, CNN MONEY (May 28, 2010, 3:39 PM), http://money.cnn.com/2010/05/28/news/economy/spain_downgraded/. 
substantial commitments of austerity from the Greek government. ${ }^{129}$ "Substantial official funds were at first used to repay private creditors under the assumption that Greek debt would be sustainable-Greece would repay all its debt including official loans." 130

However, the terms of the Greek financing satisfied few. Market actors complained that the Troika had waited too long to extend financial assistance and had provided too little in the way of loan proceeds. Others, especially Greeks, complained that the Troika had not conditioned the provision of these funds on a restructuring of Greek bonds. As a result, many argued that while rescue financing to Greece had protected bondholders, it had done so by pushing the cost of Greece's rescue financing on EU members (and their taxpayers).131 Some argued that this loan structure violated treaty obligations prohibiting public bailouts within the European Union. ${ }^{132}$ Because the IMF's policies required it to find that the rescued country's debt is sustainable before lending under its "exceptional access" criteria, others argued that the rescue package was little more than a bailout and, as such, would undermine principles of austerity and encourage sovereigns to engage in risky borrowing without fear of harsh consequences. 133 Developing nations agreed with this critique on the grounds that the "systemic exemption" to exceptional access standards favored rescue of large, developed nations over smaller, developing ones, and also on the

129. Gabi Thesing \& Flavia Krause-Jackson, Greece Gets $\$ 146$ Billion Rescue in EU, IMF Package, BLOOMBERG NEws (May 3, 2010, 4:08 AM), http://www.bloomberg.com/apps/ news?sid=aqUKEXajkSzk\&pid=newsarchive.

130. Ashoka Mody, Sovereign Debt and Its Restructuring Framework in the Eurozone, 29 OXFORD REV. ECON. POLYY 715, 727 (2013).

131. See, e.g., Charlemagne, Europe Agrees a "Shock and Awe" Bailout for Greece, THE ECONOMIST (May 2, 2010), http://www.economist.com/blogs/charlemagne/2010/05/eu rescue_greece (editorial contending that Greek restructuring "still looks horribly likely" despite rescue financing and that when default occurs "EU Political leaders will find themselves explaining to voters not just why they had to bail out Greece, but why that money may never be repaid in full, or even at all.").

132. Mody, supra note 130, at 727 ("Early on, starting with Greece, the decision was to make private creditors whole. Since that required substantial official funding for distressed sovereigns, new official financing mechanisms were set up. Whether the funding channeled through such mechanisms violates the no bailout required by the [Treaty on the Functioning of the European Union] has been a continuing source of angst.").

133. See, e.g., Silvia Ardagna \& Francesco Caselli, The Political Economy of the Greek Debt Crisis: A Tale of Two Bailouts 9 (Jan. 2014) (unpublished manuscript) (on file with the London School of Economics). 
grounds that the exemption was inherently ad hoc "since almost anything can be made to seem systemic."134

The IMF's interest in the sustainability of sovereign borrowing was neither new nor simply rhetorical. The IMF's Articles of Agreement prohibit it from lending to finance "a large or sustained outflow of capital," 135 and it has long struggled to rationalize its assessments of sustainable sovereign borrowing and the conditions it imposes on such loans; these conditions may include requirements of sovereign debt restructuring because lending at a time when a sovereign borrower has already exhibited debt problems complicates a finding of the sustainability of this debt. ${ }^{136}$ In 2002 the IMF adopted an "exceptional access" policy, conditioning certain sovereign lending on demonstration of "a high probability that the country's public debt is sustainable in the medium term' and 'a reasonably strong prospect of success" for the economic program. ${ }^{137}$

The IMF's exceptional access policy was meant to work like a precommitment device, limiting the Fund's temptation to structure help to a sovereign borrower as a loan when, in reality, the extension should be viewed as more of a bailout given the unsustainability of the lending. But like many precommitment devices, it failed. When the Greek government asked the IMF and EU officials for assistance at the height of the Global Financial Crisis, the IMF developed a "systemic" exception to this "exceptional access" policy. ${ }^{138}$ Rather than ask Greece's sovereign creditors for debt forgiveness or changes in the terms of repayment, the Troika "lent" monies to Greece. Greek sovereign borrowers were told they should tell their citizens that they should expect fewer public services or higher taxes or both. ${ }^{139}$

By the time the G-20 next met in Toronto in June of 2010, the leaders of the twenty largest economies disagreed fundamentally on the

134. See Robin Harding, IMF Discusses Third Way Over Bailouts, FINANCIAL TIMES (June 15, 2014), available at http://www.ft.com/intl/cms/s/0/713abdb8-f4a9-11e3-bf6e00144feabdc0.html\#axzz3UGp5LXh0.

135. Articles of Agreement of the International Monetary Fund, art. VI, § 1(a), adopted July 22, 1944, T.I.A.S. No. 1501, available at https:/www.imf.org/external/pubs/ft/aa/.

136. See, e.g., JAMEs Boughton ET AL., IMF Lending PraCtices AND Sovereign DebT RESTRUCTURING 1 (2014).

137. Id. at 5 .

138. IMF, Greece: Ex Post Evaluation of Exceptional Access under the 2010 Stand-By Arrangement, Country Report No. 12/156, at 1 (June 2013), available at http://www.imf. org/external/pubs/ft/scr/2013/cr13156.pdf.

139. See Jane Lethbridge, Effects of Austerity on Greece: Financing of Government Debt and Troika Intervention (Pub. Servs. Int'l, Briefing Paper, Oct. 24, 2013), available at http://www.world-

psi.org/sites/default/files/documents/research/financing_of_government_debt.pdf. 
path to economic recovery. ${ }^{140}$ Presidents Angela Merkel and Nicolas Sarkozy argued that further rescue funding would only be available if borrowing nations agreed to stringent austerity measures; ${ }^{141}$ President Obama and others argued that stimulus was important to counteract the social impacts of recession. ${ }^{142}$

Like most intractable debates, this one was rooted in ideology. John Maynard Keynes famously had remarked a generation earlier that, "the boom, not the slump, is the right time for austerity,"143 but Keynes' claim that governments should spend their way out of economic crises was steadfastly rejected by fiscal conservatives during the Great Depression; it was rejected anew during the Global Financial Crisis. For some, the comparison of a sovereign nation to an overstrapped household was impossible to set aside. "At that 2010 summit in Toronto, Germany prevailed over US objections by getting wealthier economies to commit to halving their budget deficits by 2013 and to 'stabilize,' or reduce, their debt by 2016."144 Another summit, this time between Chancellor Merkel and President Sarkozy in Deauville in October 2010, resulted in commitments to ease sovereign debt restructuring through more widespread use of collective action clauses in newly issued European bond contracts and through commitments to condition official assistance from the European Stability Mechanism on the restructuring of privately held sovereign debt. 145

That this had become a truly global financial and sovereign debt crisis had become perfectly clear by the time the G-20 leaders met in Cannes in November 2011. Weeks after the G-20 meeting in Seoul in November 2010, the Troika announced a $\$ 114$ billion rescue package to Ireland. By May 2011, it pledged a nearly identical amount to Portugal. The Memoranda of Understanding negotiated with Ireland, Greece, and Portugal specified the need for structural reform of insolvency laws, including in some cases specific reference to the desirability of

140. See, e.g., Jackie Calmes \& Sewell Chan, Leaders at Summit Turn Attention to Deficit Cuts, N.Y. TIMES, June 26, 2010, http://www.nytimes.com/2010/06/27/business/ global/27summit.html (describing debate between stimulus and austerity supporters at G20 leaders' summit in Toronto).

141. Leo Cendrowicz, How Austerity Is Tearing Apart the G-20, TIME (June 24, 2010), http://content.time.com/time/world/article/0,8599,1999444,00.html.

142. See Calmes \& Chan, supra note 140; id.

143. 21 JoHN MAYNARD KeYNES, ACTIVITIES 1931-1939: World CRISES AND POLICIES IN BRITAIN AND AMERICA 390 (Donald Moggridge ed., The Macmillan Press, Ltd. 1982) (1937).

144. Thomas Catan \& Anton Troianovski, G-20 Finance Chiefs See Growth as Priority Over Austerity, WALL ST. J. (July 21, 2013, 2:21 PM), http://www.wsj.com/articles/SB1 0001424127887324144304578619880872056430 .

145. See Mody, supra note 130, at 733. 
reforming the laws governing consumer bankruptcy or the like, ${ }^{146}$ although there were no clear international standards for consumer bankruptcy. UNCITRAL's Legislative Guide on Insolvency Law was explicitly limited to debtors with economic activity, thus excluding consumers. ${ }^{147}$ The World Bank did not issue its report on the insolvency treatment of natural persons until early 2014, and even then its report included lengthy discussion of the issues but did not include recommendations. ${ }^{148}$ In recommending structural reform of consumer bankruptcy laws, the IMF staff were shooting from the hip ${ }^{149}$ and, as a result, countries pushed back against these recommendations. 150

In July 2011, the IMF and EU officials agreed to the terms for restructuring Greece's rescue financing. ${ }^{151}$ The G-20's 2011 report conceded that "global recovery [had] weakened, particularly in advanced

146. See, e.g., Portugal: Memorandum of Understanding on Specific Economic Policy Conditionality, paras. 2.17-2.22, May 17, 2011, available at http://ec.europa.eu/economy_ finance/eu_borrower/mou/2011-05-18-mou-portugal_en.pdf; Ireland: Memorandum of Economic and Financial Policies, para. 16, July 12, 2010, available at http://ec.europa.eu/economy_finance/articles/eu_economic_situation/pdf/2010-12-07. mefp_en.pdf.

147. See UNCITRAL, Legislative Guide on Insolvency Law, supra note 59, at 38 (describing the Guide as assisting "in designing an insolvency law focused on debtors engaged in economic activities" and in a lengthy footnote broadly defining "economic activity").

148. See generally World Bank, Report on the Treatment of the Insolvency of Natural Persons (Insolvency and Creditor/Debtor Regimes Task Force, Working Paper No. ACS6818, 2014), available at http://www-wds.worldbank.org/external/default/WDS ContentServer/WDSP/IB/2014/01/23/000333037_20140123123111/Rendered/PDF/ACS681 80WP0P120Box0382094B00PUBLIC0.pdf.

149. See generally Yan Liu \& Christoph B. Rosenberg, Dealing with Private Debt Distress in the Wake of the European Financial Crisis: A Review of the Economics and Legal Toolbox (IMF, Working Paper No. 13/44, 2013), available at http://www.imf.org/ external/pubs/ft/wp/2013/wp1344.pdf (listing several factors, among them the lack of international best practices regarding such restructurings, that make these restructurings difficult endeavors).

150. See, e.g., Joseph Spooner, Sympathy for the Debtor? The Modernisation of Irish Personal Insolvency Law, 25(7) INSOLVENCY INTELLIGENCE 97, 97 (2012); Francisco Javier Arias Varona, Financial Crisis in Spain and Consumer Protection in the Absence of Special Rules for Consumer Insolvency, Unpublished Manuscript (May 2013) (on file with author); F. Javier Arias Varona, Debtor, What Debtor?, CREDIT SLIPS (Feb. 16, 2014, 4:49 PM), http://www.creditslips.org/creditslips/2014/02/the-recent-world-bank-report-on-thetreatment-of-the-insolvency-of-natural-persons-highlighted-in-its-first-pages-13-and-

ff.html; F. Javier Arias Varona, Spain, Six Years Later, CREDIT SLIPS (Feb. 12, 2014, 6:20 AM), http://www.creditslips.org/creditslips/2014/02/first-of-all-i-would-like-to-thank-thecredit-slips-team-and-in-particular-bob-lawless-for-hosting-me-here-again-i-guess.html.

151. See IMF, CoUNTRY REPORT No. 11/175: GREECE: FOURTH REVIEW UNDER THE STAND-BY ARRANGEMENT AND REQUEST FOR MODIFICATION AND WAIVER OF APPLICABILITY OF PERFoRMANCE CRITERIA 1 (2011). 
countries, leaving unemployment at unacceptable levels." 152 In addition, the depth of the European financial crisis had begun to affect global markets more broadly. Adding to their reference to problems in the United States and Europe, the G-20 Leaders' Statement also noted "signs of vulnerabilities" in emerging markets. ${ }^{153}$

The G-20 reacted to this expansion of difficulties by combining agreements on general economic and policy goals with a restatement of earlier calls for financial sector reforms. ${ }^{154}$ But still, the list of recommendations was, in important respects, limited. Although the G20 ratified "high level principles" on consumer financial protection and financial education, the G-20 remained silent on the need for international standards on consumer bankruptcy laws and residential mortgage modification. ${ }^{155}$

While the 2010 commitment to austerity held firm in 2011 and 2012 , it changed importantly over the next few years. Before the leaders of the G-20 economies met in Los Cabos, Mexico, in June 2012, the European Union and IMF announced rescue funding for Spain, but on terms noticeably less stringent in its demands for austerity. The Troika restructured Greek bonds in 2012, but did so on terms that required bondholders to share in the financial pain. "[T] he decision was to stretch out the repayment of Greece's official debt repayment obligations with the goal of lowering its debt-to-GDP ratio to about 120 per cent about a decade from now." 156 Debate continued on whether the terms of this extension of the maturity of Greece's obligations were sufficient, with many viewing the renegotiations as "too little, too late, besides being grossly unfair." 157 Perhaps in response to the perceived unfairness of extensions of Greece's obligations, the Troika subsequently agreed to "significant cumulative reduction in the Irish and Portuguese debt burdens through extended maturities and lower interest rates." 158

Despite concerns that Greek sovereign debt was unsustainable, the restructuring of Greek bonds was delayed largely out of fear that restructuring would trigger possible contagion effects. Banks in Germany, France, Belgium, and elsewhere in Europe held Greek bonds;

152. G-20 Summit on Financial Markets and the World Economy, Cannes, Fr., Nov. 4, 2011, Cannes Summit Final Declaration, para. 1.

153. See id.

154. See id. at paras. 22-34.

155. See Block-Lieb \& Halliday, supra note 2, at 3 .

156. Mody, supra note 130 , at 728 .

157. Id. "Given the sorry track record of macro projections in the first 2 years of the Greek programme, the claim that Greece would hit that precise debt ratio several years down the line was a political outcome rather than reflecting credible economic analysis." Id.

158. Id. 
it was feared that private sector involvement in the restructuring of Greek sovereign bonds would trigger financial crises elsewhere. ${ }^{159}$ In the end, the terms of this restructuring hit Cypriot banks the hardest within the eurozone, triggering a sovereign debt crisis there. ${ }^{160}$ It prompted both a Cypriot financial crisis and a Cypriot sovereign debt crisis. While resolution of circumstances in Cyprus took, in at least one view, too long, the terms of the assistance provided through the Troika differed importantly from that in other eurozone countries ${ }^{161}$ unlike the terms of any other financial assistance provided to a member of the European Union, the restructuring of Cypriot sovereign bonds and recapitalization of Cypriot banks were conditioned on the so-called "bailin" by the unsecured depositors of these banks. ${ }^{162}$

With the resolution of the Cypriot sovereign debt crisis, return to normal economic circumstances seemed plausible. Slowly over 2013, the U.S. economy began to grow more quickly than those of its European trading partners, lending support for the proposition that European policies of austerity had stifled recoveries there.

By the time of the meeting of financial leaders held in St. Petersburg in July 2013, the G-20's austerity commitment had changed: the G-20 instead emphasized that their "near-term priority is to boost jobs and growth." 163 Although German delegates pushed in this setting for a commitment that would prompt governments to define mediumterm targets for the period after 2016 to encourage "sustainable growth" not financed by borrowing, other countries in Europe and China prevailed in contending that policies fostering growth in the near term were more important. ${ }^{164}$ G-20 leaders again emphasized support for growth over austerity in the declaration emanating out of meeting in St. Petersburg in September 2013,165 and in Brisbane in November 2014. ${ }^{166}$

159. See Thomas, supra note 127.

160. See Zenios, supra note 16, at 18. While the Greek restructuring imposed losses on Cypriot banks that were slightly more than those suffered by German banks and less than those incurred by French banks, when measured as a percentage of the relevant country's GDP the impact of the Greek PSI was twice as severe on Cypriot banks than even Greek banks and higher in Cyprus than in any other Eurozone country. See id. Table 4.

161. Two hundred seventy-one days elapsed between the initial memorandum of understanding between Cyprus and the Troika and final agreement on the terms of rescue financing provided by the Troika. See id. at 4.

162. See id. at 41.

163. See Catan \& Troinovski, supra note 144.

164. See id.

165. G-20, G-20 Leaders' Declaration (Sept. 2013), https://g20.org/wp-content/uploads/ 2014/12/Saint_Petersburg_Declaration_ENG_0.pdf.

166. G-20, G-20 Leaders' Communiqué (Nov. 2014), https://g20.org/wp-content/uploads/ 2014/12/brisbane_g20_leaders_summit_communique1.pdf. 
To some extent, shifts in the austerity debate were prompted by dents that emerged in empirical support for the claim that high levels of public debt should be tempered. The case for austerity often was supported by reference to work by two Harvard economists, Carmen Reinhart and Kenneth Rogoff. Reinhart and Rogoff looked at data on sovereign debt levels spanning centuries, and concluded that once a country's sovereign debt crossed the ninety percent debt-to-GDP threshold, its economic growth plunged.167 Relying on this finding, policy makers linked policies of austerity to economic stability in the crisis context. Several years after publication, however, mistakes were found in the empirical analysis and Reinhart and Rogoff's findings were questioned. ${ }^{168}$ More recent empirical evidence more directly undermines assertions that austerity is the best medicine for recovery from a financial crisis. ${ }^{169}$ The most recent of these empirical studies emerged from economists at the IMF, who found "no evidence of any particular debt threshold above which medium-term growth prospects are dramatically compromised." 170

The consensus that collective action problems in sovereign debt restructurings were best resolved through contractual, and not statutory, measures also shifted recently. Experience with the restructuring of Argentinian sovereign bonds, which contained pari passu clauses (a contractual clause often found in sovereign debt bonds, but not one that binds dissenting holdouts to the terms of a

167. See Carmen M. Reinhart \& Kenneth S. Rogoff, Growth in a Time of Debt, 100 AM. ECON. REV.: PAPERS \& PROCEEDINGS 573, 573 (2010).

168. See Thomas Herndon et al., Does High Public Debt Consistently Stifle Growth? A Critique of Reinhart and Rogoff 1 (Political Econ. Research Inst.: Univ. of Mass. Amherst, Working Paper No. 322, April 15, 2013), available at http://www.peri.umass.edu/ fileadmin/pdf/working_papers/working_papers_301-350/WP322.pdf. See also John Cassidy, The Reinhart and Rogoff Controversy: A Summing Up, THE NEW YoRKER (Apr. 26, 2013), http://www.newyorker.com/news/john-cassidy/the-reinhart-and-rogoff-controversya-summing-up (criticizing Reinhart and Rogoff's claim that economic growth ceases once a certain debt-to-GDP ratio is reached by relying on Herndon paper).

169. See Arindrajit Dube, A Note on Debt, Growth and Causality 1 (May 30, 2013) (unpublished manuscript), available at https://dl.dropboxusercontent.com/u/15038936/ RR\%20Timepath/Dube_Growth_Debt_Causation.pdf; Miles Kimball \& Yichuan Wang, After Crunching Reinhart and Rogoff's Data, We've Concluded that High Debt Doesn't Slow Growth, QUARTZ (May 29, 2013), http://qz.com/88781/after-crunching-reinhart-androgoffs-data-weve-concluded-that-high-debt-does-not-cause-low-growth/?oref=dbamerica. .

170. Andrea Pescatori et al., Debt and Growth: Is There a Magic Threshold? 2 (IMF, Working Paper No. WP/14/34, 2014), available at http://www.imf.org/external/pubs/ft/ wp/2014/wp1434.pdf. Pescatori, Sandri and Simon qualified their conclusion somewhat, remarking that the "debt trajectory can be as important as the debt level in understanding future growth prospects, since countries with high but declining debt appear to grow equally as fast as countries with lower debt. Notwithstanding this, we find some evidence that higher debt is associated with a higher degree of output volatility." Id. 
restructuring agreed upon by a supermajority of bond creditors), suggested to some that contractual means for resolving sovereign financial distress may not alone be sufficient to promote restructuring efforts. ${ }^{171}$ A string of cases decided by federal courts in New York and affirmed by the U.S. Supreme Court first viewed the old bonds that were to be tendered by the restructuring participants as sovereign property subject to execution, and then construed pari passu clauses in restructured bonds as precluding such payments until dissenting holdouts were themselves paid in full. ${ }^{172}$ Commentators feared that this precedent might make sovereign debt restructurings more unlikely. ${ }^{173}$ Since New York law governs many sovereign bonds and empowers dissenters to insist on payment in full of sovereign debts owed to them, commentators feared that fewer sovereign creditors would agree to the terms of a restructuring. ${ }^{174}$

With strengthening economic indicators, and with the worst of the Global Financial Crisis behind us, many looked for lessons learned and returned their attention to the need for regularization in the treatment of sovereign debt restructurings. IMF staff have published several papers in the past couple of years: one, a lengthy literature survey and data analysis on the topic ${ }^{175}$ and another, a closer examination of contractual approaches to sovereign debt restructuring, focused specifically on eurozone restructurings. ${ }^{176}$ Important reports also

171. See, e.g., BROOKINGS REPORT, supra note 13.

172. See NML Capital, Ltd. v. Republic of Argentina, 727 F.3d 230 (2d Cir. 2013), cert. denied, 134 S.Ct. 2819 (2014); NML Capital, Ltd. v. Republic of Argentina, 699 F.3d 246 (2d Cir. 2012), cert. denied, 134 S.Ct. 201 (2013). The Supreme Court denied certiorari on these decisions, but is famously remembered for having affirmed another (procedural) judgment of the Second Circuit. See Republic of Argentina v. NML Capital, Ltd., 134 S.Ct. 2250 (2014), aff'g 695 F.3d 201 (2d Cir. 2012) (addressing issue of post-judgment discovery).

173. See, e.g., Floyd Norris, Argentina's Case Has No Victors, Many Losers, N.Y. TIMES, Nov. 20, 2014, http://www.nytimes.com/2014/11/21/business/international/in-argentinasdebt-case-no-winners-but-a-lot-of-losers.html?_r=0; Jamila Trindle, Argentine Default Bad Test Case for Sovereign Debt Negotiations, ForEIGN PolicY (Aug. 24, 2014), http://foreignpolicy.com/2014/08/25/argentine-default-bad-test-case-for-sovereign-debtnegotiations/.

174. See generally BROOKINGS REPORT, supra note 13.

175. See Udaibir S. Das et al., Sovereign Debt Restructurings 1950-2010: Literature Survey, Data, and Stylized Facts 5 (IMF, Working Paper No. WP/12/203, 2012), available at https://www.imf.org/external/pubs/ft/wp/2012/wp12203.pdf.

176. See Marco Committeri \& Francesco Spadafora, You Never Give Me Your Money? Sovereign Debt Crises, Collective Action Problems, and IMF Lending 13-16 (IMF, Working Paper No. WP/13/20, 2013), available at https://www.imf.org/external/pubs/ft/wp/2013/ wp1320.pdf. 
emanated from the Bank of Spain ${ }^{177}$ and the Federal Reserve Bank of Dallas. ${ }^{178}$ Reviewing experience in twelve sovereign debt restructurings, these reports argued that IMF policies had been flexible but also ad hoc, and that the lack of clear standards in this context had resulted in considerable uncertainty in the marketplace. ${ }^{179}$ This soul-searching resulted in numerous proposals for revision of the practices followed in sovereign debt restructuring, ${ }^{180}$ including a major report from the Committee on International Economic Policy and Reform, published by the Brookings Institute, ${ }^{181}$ and staff reports emanating from within the IMF. 182

Importantly, nearly all of these proposals focus on contractual measures for repairing sovereign debt restructuring practices. The IMF's return to the question of sovereign debt restructuring is not a return to the notion that some sort of mandatory procedure should be created to bind dissenters to the vote of a supermajority. Instead, after surveying various IMF policies and practices in the area and applying

177. See Javier díaz-Cassou et al., Banco de España,The Role of the IMF in RECENT SOVEREIGN DEBT RESTRUCTURINGS: IMPLICATIONS FOR THE POLICY OF LENDING INTO ARREARS (2008).

178. See Aitor Erce, Sovereign Debt Restructurings and the IMF: Implications for Future Official Interventions (Federal Reserve Bank of Dallas, Globalization and Monetary Policy Institute, Working Paper No. 143, 2013), available at http://www.dallasfed.org/assets/ documents/institute/wpapers/2013/0143.pdf.

179. See, e.g., id. at 2 . As such, it was argued that "the international community could benefit from granting the IMF a more standardized operations role ...." Id. at 1.

180. See, e.g., Christoph G. Paulus, A DeBt Restructuring Mechanism for Sovereigns: Do We NEEd a Legal Procedure? (2014); Christoph G. Paulus, A Standing Arbitral Tribunal as a Procedural Solution for Sovereign Debt Restructurings, in Sovereign DebT AND the Financial Crisis: Will This TIMe Be DifFerent? 317, 319 (Carlos A. Primo Braga \& Gallina A. Vincelette eds., 2011) (recommending the establishment of an arbitral tribunal as the cure to problems endemic to restructuring, as such a tribunal could provide a legal structure facilitating interaction between and consensus among key stakeholders); Bergljot Barkbu et al., Financial Crises and the Multilateral Response: What the Historical Record Shows, 88 J. INT'L ECON. 422 (2012) (arguing that sovereign debt "contingent convertible" bonds should exist, containing automatic provisions for restructuring whenever a country's debt-to-GDP ratio exceeded some agreed-upon level); Mody, supra note 130, at 736-741 (also arguing in favor of sovereign debt "contingent convertibles"); Lee C. Buchheit, Six Lessons from Prior Debt Restructurings, PETERSON INST. FOR INT'L ECON., 1-2 (Sept. 14, 2011), http:/iie.com/publications/papers/buchheit20110913.pdf (describing various contractual means for diluting creditors' rights when restructuring necessitated).

181. See BRookings ReporT, supra note 13 at I, III (noting that the Committee "is a non-partisan, independent group of experts, comprised of academics and former government and central bank officials" and listing its "lead authors" as Lee C. Buchheit, Anna Gelpern, Mitu Gulati, Ugo Panizza, Beatrice Weder di Mauro and Jeromin Zettelmeyer and another twelve individuals as other committee members).

182. See 2013 Staff Report, supra note 20; 2014 Staff Report, supra note 21. 
this framework to the analysis of IMF-supported initiatives between 2005 and $2013,{ }^{183}$ the 2013 staff report made few direct recommendations other than the conclusion that "debt restructurings have often been too little and too late" and have, thus, failed "to reestablish debt sustainability and market access in a durable way." 184

However, this is not to say that the 2013 IMF staff report avoided controversy altogether. After identifying various issues for possible follow up, including consideration of various ways to incentivize "the introduction of more robust aggregation clauses into international sovereign bonds," such as through conditioning use of IMF's financing "to the resolution of collective action problems,"185 paragraph thirty-two of this report indicated that IMF staff was interested in "exploring additional ways to limit the risk that Fund resources will simply be used to bail out private creditors." 186

Last year, the IMF's executive board considered the 2013 staff report but made no final decision. ${ }^{187}$ In the spring of 2014 , IMF staff published a second policy paper on sovereign debt restructuring. ${ }^{188}$ Unlike its earlier report, the 2014 staff report put a "market-based" proposal on the table. ${ }^{189}$ Specifically, the report proposed that the Fund's exceptional access policy should be revised to eliminate the 2010 systemic exemption and provide the IMF additional flexibility "in circumstances where a member has lost market access and debt is

183. 2013 Staff Report, supra note 20, at 1-2.

184. Id. at $1,7,15$.

185. Id. at 2 .

186. Id. at 26 , para. 32 .

187. At their May 2013 meeting, the IMF Executive Board noted the preliminary staff work and encouraged an additional "two-stage work program that would begin with issues related to the timeliness and adequacy of debt restructurings and collective action problems." IMF, IMF Executive Board Discusses Sovereign Debt Restructuring-Recent Developments and Implications for the Fund's Legal and Policy Framework, Public Information Notice No. 13/61 (May 23, 2013), https:/www.imf.org/external/ $\mathrm{np} / \mathrm{sec} / \mathrm{pn} / 2013 / \mathrm{pn} 1361 . \mathrm{htm}$. Without deciding the issue, a public information notice on the Board's meeting indicated that "Directors saw the benefits of focusing further work in this area on options to strengthen the existing contractual framework," but also suggested some division on whether contractual measures would be sufficient, especially given "ongoing litigation against Argentina in U.S. courts." Id. Agreeing that this litigation "could have implications for future sovereign debt restructurings," some Directors thought "a statutory framework . . . could be worth exploring" for resolution of holdout problems. Id. "Most [Directors] were also open to further examination of the merits and feasibility of possible modalities for linking Fund support to the resolution of collective action problems." Id.

188. See 2014 Staff Report, supra note 21.

189. Id. at 1 . 
considered sustainable, but not with high probability." 190 In this event, the IMF could approve access in excess of normal limits "on the basis of a debt operation that involves an extension of maturities . . .," but IMF would not engage in any other modification of the terms of the sovereign debt arrangement (that is, a modification of the timing of the debt that was owed, but without a reduction of principal or interest). ${ }^{191}$ This "reprofiling" would require creditor consent to the amended terms; while the IMF would be involved in explaining its debt sustainability analysis, it could not mandate creditors' agreement to the proposed extension of the term of the debt-collective action problems associated with this agreement would be resolved through enforcement of collective action clauses in existing sovereign bonds. ${ }^{192}$

When the IMF executive board members considered the report at the June 2014 meeting, they "saw merit" in the proposal but again looked for further consultation on the topic. ${ }^{193}$ Reaction to the proposal has been mixed. ${ }^{194}$ Perhaps importantly, the proposal attracted the

190. Id. As initially adopted in 2002, the exceptional access policy specified that the Fund could prove large scale sovereign financing above normal access limits, but that this funding would require restructuring of the sovereign's debt unless the Fund also determined after "a rigorous and systematic analysis" that there was "a high probability that the member's . . . debt" was "sustainable in the medium term." Id. at 33. In reaction to the Greek sovereign debt crisis, the exceptional access framework had been modified in 2010 to provide a systemic risk exemption for debt restructuring where "significant uncertainties" prevent categorical assurances that there is a high probability that the debt is sustainable. Id.

191. Id. at 1.

192. $I d$. at 2 .

193. IMF, IMF Executive Board Discusses the Fund's Lending Framework and Sovereign Debt, IMF Press Release No. 14/294 (June 20, 2014), http://www.imf.org/external/np/sec/pr/2014/pr14294.htm.

194. Compare Miranda Xafa, Commentary, The IMF's Lending Framework and Sovereign Debt Restructuring 2 (July 2014), http://www.cigionline.org/sites/default/ files/commentary_6.pdf (a senior fellow with the Centre for International Governance Innovation noting that the "proposed framework is a clear improvement over the systemic exemption"), and Bodo Ellmers, IMF Acknowledges Failure of Recent Debt Restructurings, Proposes New Reforms, EURODAD (May 30, 2013), http://www.eurodad.org/Entries/view/ 1545535/2013/05/30/IMF-acknowledges-failure-of-recent-debt-restucturings-proposes-newreforms (arguing that "the reforms proposed by IMF staff are certainly useful steps towards overcoming some of the flaws we have seen in recent sovereign debt restructurings" but that resolution of the issue may require UN involvement), with INSTITUTE OF INTERNATIONAL FINANCE SPECIAL COMMITTEE ON FinaNCIAL Crisis PREVENTION AND RESOLUTION, VIEWS ON THE WAY FORWARD FOR STRENGTHENING THE FRAMEWORK FOR SOVEREIGN DEBT RESTRUCTURING 3 (Jan. 2014), http://www.iif.com/news/capital-markets-and-emerging-markets-policy/iif-specialcommittee-financial-crisis-prevention (noting concerns "that adoption of the 'presumption' of creditor involvement at the outset of new IMF programs would signal a new, more 
attention of the Russian diplomats involved in the G-20's meetings in St. Petersburg. ${ }^{195}$ Following meetings in Brisbane in 2014, the G-20 Leaders' Communiqué again reported approval of progress that had been made on this issue. ${ }^{196}$

Among recent proposals for reform of sovereign debt restructuring practices, only the Brookings Report has advocated the need for a statutory response to practices in sovereign debt adjustment. ${ }^{197}$ It proposes the creation of a Sovereign Debt Adjustment Facility (SDAF) that looks to address IMF handling of sovereign debt with "a significant risk of being unsustainable." 198 While in principle the IMF should not be lending in this instance at all, in practice political pressure to provide assistance is nearly irresistible, contends the Report. To address this practice, the Brookings Report proposes the creation of an SDAF that would transparently address the problem of debt that may well be unsustainable. This SDAF would differ significantly from the SDRM proposed by the IMF in 2001199_specifically, it would limit access to SDAF funding based on a state's application, followed by a draft Debt Sustainability Analysis that would form the basis for multilateral negotiations; these negotiations would lead to restructuring of the state's sovereign debt with the goal of support by "at least 75 percent of the affected debt instruments." ${ }^{200}$ Rather than staying holdouts'

demanding and rigid policy rule" which would "undermine market confidence" and "raise problems of moral hazard").

195. Although the issue of sovereign debt restructuring was not itself addressed by the G-20 in St. Petersburg Leaders' Statement, the IMF's renewed interest in the topic was commented on in a press conference held at the close of that meeting. See Press Release, Outcomes of the G-20 Presidency, http://g20russia.com/en/presseng/item/891-outcomes-ofthe-russian-g20-presidency.html.

196. G-20, G-20 Leaders' Communiqué, Brisbane Summit, para. 12 (Nov. 15-16, 2014), http://g20watch.edu.au/sites/default/files/pictures/brisbane_g20_leaders_

summit_communique.pdf (welcoming progress in strengthening "orderliness and predictability of the sovereign debt restructuring process").

197. See generally BROOKINGS REPORT, supra note 13. Indeed, this report looks to minimize the difference between the sovereign debt adjustment facility that it recommends and the "strong form" of CACs it proposes. Id. at v. "The main difference between the two proposals is that the second would do more to correct biases that delay necessary debt restructuring" in part because "the IMF-based proposal would have immediate effects, while better collective action clauses would become effective only gradually, as existing debt is replaced by newly issued debt." $I d$.

198. Id. at 32 .

199. Id. at 34 (noting that "[u]nlike the SDRM, there would not [sic] be no automatic stay of litigation; no tribunal to hear disputes between the debtor and its creditors; and no mechanism for binding all creditors to the will of the supermajority" and that "the main emphasis of the SDAF, unlike the SDRM, would be to establish a commitment device that would preclude the Fund from financing countries with doubtful debt sustainability').

200. $I d$. 
litigation, the SDAF would "defang" these suits by immunizing the assets and revenue streams of a debtor country against attachment-a protection that appears to resemble exemption laws that identify an individual borrower's assets that are free from the reaches of specified collecting creditors. ${ }^{201}$ But both the SDRM and SDAF suggest mandatory relief beyond mere contractual resolution of sovereign debt problems.

\section{COMPARING SOVEREIGN AND CONSUMER BORROWERS}

Sovereign debt has been viewed, conventionally, as a puzzle: although lenders' remedies for enforcement of sovereign debt are limited, sovereign borrowers have nonetheless historically borrowed, and sovereign lenders lent, substantial amounts. ${ }^{202}$ Addressing this puzzle, modern economic literature has asked why sovereign debt got paid at all and "concluded that borrowers repay because defaults are economically costly for the debtor country."203 Based on this logic, commentators argued that "attempts to reduce the costs of default could also reduce welfare because they would make sovereign debt more expensive and lower the maximum level of debt that a sovereign can accumulate." On these grounds, commentators opposed proposals to make sovereign debt restructuring easier. ${ }^{204}$ Based on this logic, nothing like Chapter 11 was needed to resolve sovereign debt problems.

But modern economic literature on sovereign debt has been chasing the wrong metaphor. The puzzle of sovereign debt shifts when sovereign borrowing is viewed through the lens of consumer (not corporate) borrowing. This shift promises more than a new rhetoric. The sections below outline some of the implications of this changed perspective.

\section{A. Why Lenders Lend and Borrowers Do Not Always Default When Assets Provide No Backstop}

Consumer credit (especially the unsecured variant, such as that of a credit card credit) differs from corporate lending. When the debtor is a corporation or similar legal person, its creditors can force repayment through a sale of the corporation's assets. But these powers are "partitioned" in that they are limited to the assets of the corporation;

201. Id.

202. See id. at 5 (noting that sovereign remedies "are limited by the fact that most sovereign assets are located within a sovereign's jurisdiction and cannot be seized, even when creditors have won in court").

203. Id.

204. Id. 
the corporate form means that shareholders enjoy "entity protections" in that a corporation's creditors cannot force a sale of the assets of the corporation's owners or other entities. ${ }^{205}$ When viewed from the perspective of creditors' remedies on default, all corporate lending, whether secured or not, is a sort of "asset-based lending."

By contrast, consumer credit often is not extended based solely on a borrower's assets. Although a consumer's lender could force a sale of the borrower's assets in the event of a default, largely these household goods hold little value and may be exempted at law from the reach of creditors. Credit card issuers extend credit primarily based on a borrower's income and her willingness and ability to repay. ${ }^{206}$

Sovereign lenders make essentially the same calculus as consumer lenders, although sovereign "income" comes from an entire economy of workers and their tax commitments. Like consumer lenders, sovereign lenders know that they are unlikely to be repaid out of the borrower's assets. Sovereign lenders also know that repayment from sources other than forced asset recoveries will be difficult. Although neither sovereign nor consumer lenders can force repayment from their debtors' "income" without restrictions of some sort, ${ }^{207}$ both sorts of lenders extend credit based on ex ante assessment of historical accounts of the debtor's payment and default practices. Both sovereign and consumer borrowing are, from this perspective, better viewed as "income-based lending." Income-based lending generally is profitable because, by and large, debtors repay their debts, if not on time then at least eventually.

Sophisticated mathematical models assist both sorts of lenders in making ex ante assessments about borrowers' likelihood of repayment. This modeling allows them to predict default rates, and thus also allows them to set pricing at levels that ensure healthy profits. Securitization of both household and sovereign debt allows for further sorting according to taste for risk, with the most risk averse lenders buying

205. See, e.g., Henry Hansmann, Reinier Kraakman \& Richard Squire, Law and the Rise of the Firm, 119 HARV. L. REV. 1333, 1337 (2006) (describing corporations as providing asset partitioning and entity shielding functions).

206. Indeed, arguments favoring a means-tested Chapter 7 were based on assertions that credit card lending had shifted from asset based to income based lending. See, e.g., Raymond T. Nimmer, Consumer Bankruptcy Abuse, 50 LAW \& CONTEMP. PROBS. 89, 96 (1987).

207. As a matter of public policy, countries may protect a portion of a debtor's wages from execution. Certain assets may be protected from creditor collection, and assets that aid the debtor's earning capacity are likely to be exempt from the reaches of creditors precisely because policy interests in enforcing creditors' claims are not understood to trump the debtor's ability to earn the wages needed for repayment. Moreover, certainly in the United States, but also in other countries, a debtor can obtain a "discharge" from debt that remains unpaid after some bankruptcy process has been concluded. For general discussion of these issues of consumer collection law, see World Bank, supra note 148. 
related asset-backed securities with AAA ratings, and the most risk preferring of these lenders buying "junk bond" rated securities that promise far higher returns in exchange for heightened risks. And supplementing these securities with credit default swaps or other derivatives also shifts some of the heightened risks associated with this debt.

\section{B. Why Restructuring Is So Difficult}

Comparing sovereign debt to consumer debt also clarifies the difficulties of restructuring either sort of obligation. The securitization of Brady bonds in the late 1980 s meant that sovereign debt was extended privately, not by a handful of globally powerful banks, but instead by a large number of bondholders. ${ }^{208}$ Policy makers feared that sovereign debt restructuring would become even more difficult than it had been in the past because reaching near unanimous agreement with a large number of actors is far more difficult than reaching near unanimous agreement with a small number of actors. But in the 1990s and 2000s, and even more recently, collective action problems of this sort did not plague most sovereign debt negotiations. ${ }^{209}$ Recent litigation between hedge fund holdouts and Argentina might be viewed as confirmation that holdouts constitute the biggest impediment to sovereign debt restructuring. ${ }^{210}$

The biggest problem that both sovereign and consumer lenders face in trying to restructure debts premised on their borrowers' ability to pay is that restructuring - that is, a negotiated reduction in the effective interest rate or outstanding principal amounts of these loans-is only rational for "income-based" lenders when lenders are convinced that the debtor cannot pay, not just unwilling to pay. And that takes a lot of convincing, especially in the case of sovereign debt. Measurements of ex ante ability to pay and ex post sustainability are fraught with difficulty in both consumer and sovereign debt contexts.

208. See Adam Feibelman, American States and Sovereign Debt Restructuring, in WHEN STATES Go Broke: THE ORIGINS, ConTEXT, AND SOlutions FOR THE AMERICAN STATES IN FISCAL CRISIS 146, 161 (Peter Conti-Brown \& David A. Skeel, Jr. eds., 2012).

209. See, e.g., Das et al., supra note 175, at 43-45; Committeri \& Spadafora, supra note 176 , at $7-9$.

210. See UN Agency Warns Argentina Debt Ruling Does not Comply with US Sovereign Immunities Act, MERCOPRESS (June 26, 2014, 4:40 AM), http://en.mercopress.com/2014/06/ 26/un-agency-warns-argentina-debt-ruling-does-not-comply-with-us-sovereign-immunitiesact. 
Moreover, these assessments become even more difficult as the term over which these debts are repaid increases. ${ }^{211}$ In theory (and absent a discharge in bankruptcy), consumers can apply income to repayment of their debts as long as they can work, and possibly longer if other sources of income can be applied to debt repayment (or if debts are inherited by other members of the debtor's family); in theory, sovereign debt is owed "forever," unless lenders agree to forgive or restructure the outstanding amount or it is repaid in full. ${ }^{212}$ Given the potential for such long horizons, even where lenders are convinced that the borrower's debt is currently unsustainable, lenders may refuse to forgive the debt if they think that the debtor's circumstances are subject to change.

Assessment of measurements of the sustainability of consumer debt levels has been contentious. The 2005 amendments to U.S. consumer bankruptcy law sought to limit access to Chapter 7 liquidation to those individuals whose consumer debts were not repayable within a five-year period. ${ }^{213}$ These amendments took discretion away from bankruptcy judges and substituted in its place a complex formula for assessing consumer debtor's ability to repay outstanding indebtedness. ${ }^{214}$ These means-testing provisions were - and remain-hotly debated.

Debate on when consumer debt ought to be discharged is not unique to the United States. Within Europe, there is little agreement as to whether debt adjustment or some other sort of consumer bankruptcy legislation generally should be adopted; although members of the European Union otherwise have agreed to harmonize a wide range of laws governing litigation procedure, as well as the substantive laws governing commercial and financial transactions, consumers' access to insolvency relief differs substantially in Europe.215 And outside

211. Even where the debt is structured to mature on a particular date, these terms are flexible given options to roll over old debt into new debt with an extended due date.

212. See BROOKINGS REPORT, supra note 13, at 15 (noting that "although sovereign debt contracts are hard to enforce, they also last forever"); see also Stephen Castle, That Debt from 1720? Britain's Payment Is Coming, N.Y TIMEs, Dec. 27, 2014, http://nyti.ms/ $1 \mathrm{Bf} 3 \mathrm{WOb}$ (discussing recent news reports of Britain's repayment in full of bonds initially issued in the eighteenth century).

213. See 11 U.S.C. $\S 707($ b)(2)(A)(i), (b)(V)(iii) (2014). See also Jean Braucher, Means Testing Consumer Bankruptcy: The Problem of Means, 7 FORDHAM J. CoRP. \& FIN. L. 407 (2002).

214. See Braucher, supra note 213 , at 448 .

215. This dissensus may change in the medium term as the European Commission has signaled its interest in greater harmonization of insolvency laws involving individual entrepreneurs. See, e.g., Commission Recommendation on a New Approach to Business Failure and Insolvency, COM (2014) 1500 final (Dec. 3, 2014) (discussing a recent proposal by the European Commission urging greater convergence in this area). Agreement on European standards for the insolvency treatment of consumer debtors is not recommended in this report, however. 
Europe -in Asia and Africa especially, but also generally-consumers find little in the way of debt relief. ${ }^{216}$

The fact that assessment of unsustainable sovereign debt is complicated would come as no surprise to policy makers immersed in assessing the sustainability of consumer debt levels. Much of the problem with the IMF's extensive access policies, premised on a finding that sovereign debt is sustainable with a high degree of probability, is that its Debt Sustainability Analyses (DSAs) are based on a combination of quantitative (economic) and qualitative (political) factors. ${ }^{217}$ The systemic exception to this policy that the IMF developed when assessing the sustainability of Greek sovereign lending added fuel to the fires that raged on this topic. ${ }^{218}$

Recent proposals to reprofile sovereign debt in the gray area between debt that is sustainable with a high degree of certainty and debt that is more likely unsustainable removes the politically difficult requirement that any new lending should be conditioned on restructuring of existing debt, but it does not remove responsibility for assessing the sustainability of this debt. ${ }^{219}$ Indeed, the decision to reprofile may depend more heavily on a sustainability analysis than did earlier systemic assessments. Assessment of the process for developing these DSAs is, thus, an important part of determining the workability of this reform proposal.

The SDAF proposed by the Committee on International Economic Policy and Reform looks to pave a way around "a 'gray area' in which predefined criteria raise doubts about the lack of debt sustainability," but to which few want to commit. 220 The Committee has argued that the primary benefit of its proposal is that an SDAF would limit the IMF's flexibility in this gray zone. ${ }^{221}$ Comparison of sovereign to consumer financial distress suggests another benefit: the Facility would add substantial transparency and stakeholder involvement to the process through which DSAs are produced, as well as offer a forum for all interested parties to buy into the assessment that a sovereign's debt is sustainable, or is only sustainable if specified restructuring is pursued.

216. See, e.g., Soogeun Oh, Insolvency Law Reform of Korea: A Continuing Learning Process 8-9 (Dec. 16-17, 2002) (unpublished manuscript) (on file with author), http://www.oecd.org/daf/ca/corporategovernanceprinciples/2490824.pdf.

217. See IMF, Staff Guidance Note for Public Debt Sustainability Analysis in MarketAccess Countries (May 9, 2013), http://www.imf.org/external/np/pp/eng/ 2013/050913.pdf; IMF, Modernizing the Framework for Fiscal Policy and Public Debt Sustainability Analysis (Aug. 5, 2011), http://www.imf.org/external/np/pp/eng/ 2011/080511.pdf.

218. See IMF, supra note 138.

219. See 2014 Staff Report, supra note 21 , at 1.

220. BROOKINGS REPORT, supra note 13 , at 33 .

221. Id. 
Thus, given lenders' limited incentives to restructure "incomebased" loans, it seems miraculous that any sort of debt reduction occurs on a voluntary basis, especially when the debtor owes numerous creditors who must all be convinced of the wisdom of debt adjustment.

\section{Why Borrowers Borrow Too Much, Why Lenders Are Fine With That, and the Implications of Both for Restructuring Policies}

But there is even greater reason for concern about the ex post incentives associated with "income-based" lending, because comparison of consumer to sovereign debt also explains pathologies in ex ante incentives in this context. Consumer borrowers may overborrow because they do not act like the rational decision makers that economic models would posit: behavioral decision research suggests that individuals make errors in comparing short- and long-term costs and that framing of the costs can distort consumers' perceptions; it also suggests that consumers can be overoptimistic about their prospects for income growth and whether shocks to their earnings capacity will disrupt income. ${ }^{222}$

Like consumer borrowers, sovereign borrowers face incentives to overborrow, although for different reasons. Sovereign debtors' pathologies arise more from agency problems than from cognitive limitations. A sovereign's self-interested politicians have every incentive to borrow to provide short-term benefits in the next election, but this borrowing imposes costs further down the road for their successors. ${ }^{223}$ Compounding incentives to overborrow, consumer lenders and sovereign lenders also face market incentives to overlend. As with overborrowing, the causes for overlending differ depending on the nature of the lenders' borrower. The result is the same in both cases, however: too much debt.

Some consumer lenders structure their businesses on the backs of debtors in default. More than simply collecting the additional fees and higher interest in a default context, payday lenders, for example, lend on a very short-term basis, although a majority of their borrowers

222. For greater detail on pathologies in consumers' cognitive decision making, see OREN BAR-GILl, SEDUCTION BY CONTRACT: LAW, ECONOMICS, AND PSYCHOLOGY IN CONSUMER MARKETS (2012); Oren Bar-Gill, The Law, Economics and Psychology of Subprime Mortgage Contracts, 94 CORNELL L. REV. 1073 (2009); Oren Bar-Gill \& Elizabeth Warren, Making Credit Safer, 157 U. PA. L. REV. 1 (2008); Oren Bar-Gill, Bundling and Consumer Misperception, 73 U. CHI. L. REV. 33 (2006); and Susan BlockLieb \& Edward J. Janger, The Myth of the Rational Borrower: Rationality, Behavioralism, and the Misguided "Reform" of Bankruptcy Law, 84 TEX. L. REV. 1481 (2006).

223. See BROOKINGS REPORT, supra note 13, at 8 (arguing that "policymakers often have incentives to borrow more than what is socially optimal"). 
extend this loan for additional periods. ${ }^{224}$ Payday lending may exceed welfare-optimizing levels and yet remain profitable for payday lenders. ${ }^{225}$ Moreover, payday lenders are not the only consumer lenders suspected of lending in excess of socially optimal levels. The foreclosure crisis in the United States has been attributed, in large part, to the securitization of high-risk subprime residential mortgages loans. The tranching of pools of subprime mortgages and issuance of Residential Mortgage Backed Securities (RMBS) to the capital markets allowed the risk averse to purchase market-grade RMBS, which they demanded at unprecedented levels. Many argue that high demand for RMBS created excessive supplies of subprime mortgages. ${ }^{226}$

Sovereign lenders' incentives to overlend are distinct from consumer lenders' incentives to overlend. Sovereign lenders' overlending may well be, at least in part, attributable to the moral hazard created by the expectation of official sector bailouts. Bailouts from international lenders of last resort create incentives for sovereign creditors to "behave recklessly and lend without adequate regard to risk because official bailout packages may allow for repayments that are 'too high' with respect to the social optimum."227 The cost of rescue loans are externalized, not by "global taxpayers but by local taxpayers who end up repaying, even when it would have been better to restructure."228

Overlending to sovereigns might also occur because of the absence of seniority rules associated with sovereign debt repayment. Some argue that new loans provided to countries whose debt burdens are already

224. See, e.g., Brian T. Melzer, The Real Costs of Credit Access: Evidence from the Payday Lending Market, 126 Q. J. ECON. 517, 523 (2011).

225. See, e.g., Leslie Parrish \& URiah King, Phantom Demand: Short-Term Due Date Generates NeEd for Repeat Payday LoANS, AcCounting For 76\% of Total Volume 19 (2009). But see Donald P. Morgan, Defining and Detecting Predatory LENDING 22-23 (Fed. Reserve Bank of N.Y. Staff Report No. 273, 2007) (concluding that payday lending may not be "predatory" where borrowers are not more likely to miss payday loan payments than other loan payments, but that it may be more expensive than similar forms of credit depending on market concentration and competition).

226. See, e.g., Kathleen C. Engel \& Patricia A. McCoy, The Subprime Virus: RECKLESS CREDIT, REGULATORY FAILURE, AND NEXT STEPS 71 (2011).

227. BROOKINGS REPORT, supra note 13, at 8. See also BARRY EICHENGREen ET AL., PUBLIC DEBTS: NUTS, BOLTS AND WorRIES (Geneva Rep. on the World Econ. 13th ed. 2011) (discussing the long-term perspective on debt sustainability and arguing that fiscal stabilization is easier the faster the economy is growing).

228. BROOKINGS REPORT, supra note 13, at 8-9 (noting also that while this lender "moral hazard can be mitigated by designing official rescue packages that 'bail-in' private creditors" these sorts of bail-ins only get negotiated ex post and so "may not be optimal . . .). See also Olivier Jeanne \& Jeromin Zettelmeyer, International Bailouts, Moral Hazard and Conditionality, 16 ECON. POL'Y 407-32 (2001) (arguing that availability and size of official crisis lending for international bailouts need to be conditional on government policies before the crisis). 
high can "dilute" the claims of existing creditors, and that this debt dilution can lead to overborrowing and overlending because the marginal interest rates on which the new loan is extended do not reflect the increase in risk that these new loans present more generally to the debtor. ${ }^{229}$ Econometric analysis provides further support for the claim that this dilution affects sovereign debt default risks. ${ }^{230}$

Others argue that herding behaviors may explain sovereign lenders' willingness to "take on too much risk during periods of global optimism"231_a phenomenon with econometric support. ${ }^{232}$ Herding behaviors may also cause lenders to liquidate good loans when others in the market are also selling, ${ }^{233}$ and economic research similarly demonstrates that sovereign debt markets may suddenly freeze in the face of a global shock, based on a presumption that the loans are not sustainable. ${ }^{234}$

Finally, these incentives can accumulate. When consumers' ex ante tendencies to overborrow and lenders' ex ante incentives to overlend are combined with inherent difficulties in assessing the sustainability of

229. See Patrick Bolton \& Olivier Jeanne, Structuring and Restructuring Sovereign Debt: The Role of a Bankruptcy Regime, 115 J. POL. ECON. 901, 920 (2007). See also EdUARdo Borensztein ET AL., SOVEREIGN DebT Structure For CRISIS PREvention, IMF Occasional Paper WP/237 (2004) (discussing the costs and benefits of different sovereign debt structures for crisis prevention). See generally, BROOKINGS REPORT, supra note 13 , at 9 (discussing this scholarship).

230. See generally Juan Carlos Hatchondo, Leonardo Martinez \& César Sosa Padilla, Debt Dilution and Sovereign Default Risk, (IMF, Working Paper WP/11/70, 2011), available at https://www.imf.org/external/pubs/ft/wp/2011/wp1170.pdf (proposing a modification to a baseline sovereign default framework which allows for consideration of the level and volatility of the interest rate spread paid by sovereigns through quantification of the importance of debt dilution).

231. BROOKINGS REPORT, supra note 13, at 9.

232. Id. See also Ugo Panizza, Federico Sturzenegger \& Jeromin Zettelmeyer, The Economics and Law of Sovereign Debt and Default, 47 J. ECON. LITERATURE 651-98 (2009) (examining recent literature on sovereign debt and relating it to the evolution of the legal principles underlying the sovereign debt market); Salvatore Dell'Erba, Ricardo Hausmann \& Ugo Panizza, Debt Levels, Debt Composition, and Sovereign Spreads in Emerging and Advanced Economies (Harvard Kennedy School of Government, Working Paper No. 263, 2013) (studying the interaction between debt composition and debt levels in advanced and emerging market countries); COMM. ON INT'L ECON. POL'Y \& REFORM, BANKS AND CROSSBorder Capital Flows: POLICY Challenges and Regulatory Responses (2012) (proposing a framework for cross-border banking flows and for improved coordination of debt regulation).

233. See generally Franklin Allen, Stephen Morris \& Hyun Song Shin, Beauty Contests and Iterated Expectations in Asset Markets, 19 REV. FIN. STUD. 719-52 (2006) (discussing general herding behaviors).

234. See generally Gulllermo A. Calvo, Emerging Capital Markets in TURmoil: BaD LUCK OR BAD POLICY? (2005) (examining issues of market fluctuations from the perspective of emerging market economies themselves). 
these debts ex post and in restructuring these obligations in times of financial crisis ex post, the situation can turn toxic.

Both the Committee on International Economic Policy and Reform and the IMF detail extensive support for the claim that sovereign debt restructuring occurs too late to make a difference. ${ }^{235}$ Undoubtedly, the causes of this delay are partly political. Some commentators argue that delays in restructurings occur as a result of agency costs inherent in democratic political structures. ${ }^{236}$ Self-interested politicians have every incentive to delay debt renegotiations, which are painful and costly for their constituents. Short-term political horizons create incentives for these politicians to borrow their way out of financial difficulties, knowing that the full costs of these loans are unlikely to be felt until after they have left office.

An IMF 2013 staff report supports this argument with numerous anecdotes of countries' decisions to restructure coming only after market access is lost and well after IMF staff information of unsustainable debt levels. ${ }^{237}$ The Committee on International Economic Policy and Reform succinctly details the consequences of this delay as follows:

Delayed defaults can lead to the destruction of value because a prolonged predefault crisis may reduce a country's capacity and willingness to pay. Its capacity to pay is reduced because procrastination prolongs the climate of uncertainty, high interest rates and restrictive fiscal policies that are ineffective in avoiding default but amplify output contractions. Delayed defaults reduce its willingness to pay because electors that have suffered long periods of economic austerity are

235. See 2013 Staff Report, supra note 20; BROOKINGS REPORT, supra note 13, at 10-12. See also Eduardo Borensztein \& Ugo Panizza, The Costs of Sovereign Default, 56 IMF STAFF PAPERS 683-741 (2009) (evaluating reputational costs, international trade exclusion costs, costs to the domestic economy through the financial system, and political costs, in order to contrast the costs of a sovereign default with the political consequences of a debt crisis); Eduardo Levy Yeyati and Ugo Panizza, The Elusive Costs of Sovereign Defaults, 94 J. DEv. ECON. 95-105 (2011) (using quarterly data to determine that default episodes mark the start of economic recovery, and that the negative effects of a default are likely to be driven by the anticipation of default, regardless of whether the entity actually defaults or not).

236. See generally Viral V. Acharya \& Raghuram G. Rajan, Sovereign Debt, Government Myopia, and the Financial Sector, 26 REV. FIN. STUD. 1526-60 (2013) (analyzing the factors that determine the sustainability of sovereign debt). See also BROOKINGS REPORT, supra note 13 , at 10.

237. See 2013 Staff Report, supra note 20. See also BROOKINGS REPORT, supra note 13 , at 11. 
less likely to support a creditor-friendly debt restructuring. ${ }^{238}$

Adding to this, the IMF and others find that sovereign debt restructurings often seek "too little" in the way of debt reduction, which has meant that sovereign borrowers frequently face continued financial difficulty after a restructuring. ${ }^{239}$ Powell and others argue that this situation creates the possibility of "two, equally bad, equilibria." 240 These problems may also be exacerbated by "overoptimistic debt sustainability assessments, with relatively small face-value haircuts that did not restore debt sustainability, required prolonged official support and led to additional restructurings." 241

\section{Lessons Learned in the Consumer Context}

Comparing sovereign to consumer borrowers does not provide ready solutions to the sovereign debt crises that continue to plague world markets. That is not surprising, for several reasons. First, as noted above, consumer debt adjustment is redistributive. Whereas corporate reorganization can be claimed to present a "win-win" solution for creditors because a corporate debtor's going concern values are preserved and shared with stakeholders with no claim beyond their borrower's liquidation values, the same sort of argument is unconvincing in a consumer context. It is harder to argue that creditors "do better" in a restructuring than they otherwise would have. The case for discharging unsustainable consumer debt is built more broadly on social welfare grounds than in terms of the benefits of consumer debt adjustment to lenders.

Second, unlike with corporate insolvency law, there are no international standards regarding the desirability or contents of consumer bankruptcy laws (or related laws to address consumer overindebtedness). ${ }^{242}$ Global consensus on the need for restructuring and reduction of consumer debt levels has, thus far, eluded the international community, but support for developing international standards in the

238. BROOKINGS REPORT, supra note 13 , at 10.

239. See 2013 Staff Report, supra note 20. See also BROOKINGS REPORT, supra note 13, at 11 .

240. Brookings Report, supra note 13, at 11. See also Andrew Powell, Bipolar Debt Restructuring: Lessons from LAC, Vox LACEA (Feb. 24, 2011) (arguing that modern debt restructuring schemes are ineffective), http:/vox.lacea.org/?q=debt-lessons-LAC.

241. BROOKINGS REPORT, supra note 13, at 12 (discussing 2013 Staff Report, supra note 20).

242. See Liu \& Rosenberg, supra note 149, at 12. 
consumer context is building. The World Bank report on the insolvency treatment of natural persons is one such indication. ${ }^{243}$ Work within the European Commission presents another. ${ }^{244}$ Experience under a broad range of national efforts to adopt or reform domestic consumer bankruptcy laws might also inform those interested in sovereign debt restructuring practices.

How has the problem of overindebted consumers been addressed globally, how successful have these efforts been, and what are the implications from the consumer context for that involving sovereign borrowers? A quick outline of important areas of overlap would include the following:

\section{Unfettered Discharge of Debt}

Between 1898 and 2005, the United States allowed individual debtors (including consumers debtors) unfettered access to liquidation in bankruptcy, placing few obstacles in front of the bankruptcy discharge available in these Chapter 7 liquidation cases. ${ }^{245}$ With 2005 amendments to the Bankruptcy Code, the United States began to condition the bankruptcy discharge on requiring individual debtors to demonstrate their "need" for such relief by satisfying a complex "means test." 246 While neither courts nor creditors are permitted to force an individual into a Chapter 13 debt repayment plan under U.S. law, as a practical effect, these 2005 amendments work to condition discharge on

243. See generally World Bank, supra note 148 (providing a report on the characteristics of the insolvency regime of natural persons and issues that need to be addressed by policymakers in different communities).

244. See generally Iain Ramsay, Two Cheers for Europe: Austerity, Mortgage Foreclosures and Personal Insolvency Policy in the EU, in CONSUMER DEBT AND SOCIAL EXCLUSION (Irina Domurath \& Hans-W. Micklitz eds., forthcoming July 2015) (discussing the effects of the modern financial and economic crisis by analyzing the social goal of inclusion and the effect of social exclusion through overindebtedness since 2008 in Europe).

245. But see 11 U.S.C. $\$ \S 523,727$ (2012) (setting out debts excepted from discharge for policy reasons, and circumstances that preclude debtors from obtaining any discharge out of the liquidation case).

246. Because the "means test" is mostly triggered under 11 U.S.C. $\S 707$ for individuals earning more than the median income for the state in which they reside, and because most individual debtors earn less than the median income in their state, this "means testing" did not preclude a quick bankruptcy discharge in Chapter 7 for most individual debtors. Nonetheless, "means testing" has significantly affected consumer bankruptcy practices in the United States since it was adopted in 2005. See generally Braucher, supra note 213 (discussing the implications of this 2005 amendment to the U.S. Bankruptcy Code). 
repayment of debt over a three- to five-year-long period. ${ }^{247}$ Thus, the comparison of sovereign to consumer indebtedness may support instincts not to forgive sovereign debt too readily. Conditional discharge is the norm in the consumer setting, 248 and conversations about sovereign debt forgiveness should address this norm.

\section{Conditional Discharge of Debt}

The World Bank Report on the Insolvency Treatment of Natural Persons notes an emerging global consensus that an individual's access to a discharge from over-indebtedness should be conditioned on courtsupervised repayment of such debts over some period. ${ }^{249}$ Under U.S. Chapter 13 debt repayment plans, repayment obligations often stretch over a five-year period. ${ }^{250}$ In Germany, this period may take up to six years. $^{251}$ Other countries impose shorter probationary periods; for example, in England and Wales, a discharge generally is available after one year of repayment experience. ${ }^{252}$ Although international standards do not exist regarding the length of these payment periods, ${ }^{253}$ together these domestic debt adjustment laws suggest a solution to the difficulties of assessing what debts are "sustainably" imposed on an individual debtor: once an eligible debtor seeks protection from its creditors, domestic legislation presumes that repayment in excess of the statutory period is not sustainable, without requiring individuated

247. Creditors cannot push a debtor into a Chapter 13 case involuntarily. See 11 U.S.C. $\S 303(\mathrm{a})$ (permitting involuntary cases "only under Chapter 7 or 11 of this title"). The voluntariness of Chapter 13 is partly based on policy concerns that obligations to repay creditors are unworkable and partly on a fear that such a mandate would contravene constitutional proscriptions on peonage. See also Karen Gross, The Debtor As Modern Day Peon: A Problem of Unconstitutional Conditions, 65 NOTRE DAME L. REV. 165 (1990) (discussing relationships between debtors and creditors and the bankruptcy implications of these relationships).

248. See World Bank, supra note 148, at 115; Liu \& Rosenberg, supra note 149 (comparing consumer insolvency laws and noting their systemic importance).

249. See World Bank, supra note 148, at 115 .

250. See 11 U.S.C. § 1325(b)(4) (2012).

251. See, e.g., Michael Knobloch, Unemployment and Over-Indebtedness in Germany, in CONTEMPORARY ISSUES IN CONSUMER BANKRUPTCY 215 (Wolfram Backert et al., eds., 2013) (in context of examining the causal relationship between unemployment and overindebtedness in Germany and analyzing the programs that seek to minimize that relationship, noting details of German consumer debt adjustment laws).

252. See, e.g., LAIN Ramsay, Consumer LAW and Policy: TeXT and Materials on REGULATING CONSUMER MARKETS, at 493-95 (3rd ed. 2012).

253. See Liu \& Rosenberg, supra note 149. 
assessments of the sustainability of plan payments. ${ }^{254}$ Where discharge is conditioned on something other than completion of some probationary payment period, it is often conditioned on demonstration of the debtor's abject poverty: Here, sovereign debt practices could learn from consumer debt repayment practices that conditional discharge motivates a borrower's repayment of sustainable debt obligations over the statutorily set period. Sovereign debt forgiveness might be held in abeyance-like a carrot before the donkey-pending payment over some lengthy period (presumably much longer than the emerging international norm of three to five years for individual debtors).

\section{Exempt Property}

Whether or not a country provides individuals with the possibility for a discharge from unsustainable debt through bankruptcy processes, it might also protect overindebted debtors from the prospect that debt collection efforts will render them destitute by identifying certain property as "exempt"-that is, as free from the reaches of creditors. Based on these exemption laws, individual borrowers, although in default and the subject of collection action, can continue to work and protect at least some of their least valuable possessions. Sovereign borrowers might similarly ring fence certain types of assets as "exempt" and outside the reach of any sovereign lender.

\section{Responsible Lending Regulation}

Perhaps the most extreme difference between sovereign debt and consumer debt is the complete absence of regulation of lending practices in the sovereign debt context. Although international organizations have begun to question whether sovereign debt problems should be viewed as lending problems, not just problems of collection, ${ }^{255}$ international organizations and international financial institutions generally have ignored the benefits of a shift from ex post to ex ante examination of sovereign debt problems.

By contrast, consumer lending is heavily regulated throughout the globe. Increasingly, nations look carefully and require their consumer lenders to look carefully at whether consumer borrowers have an "ability to repay" their debts. This scrutiny is required to take place ex

254. Some countries permit discharge without the need for lengthy debt repayment experience if the court or a supermajority of creditors determines that current debt levels are unsustainable.

255. This absence exists despite some efforts by the UN's Conference on Trade and Development to adopt "principles" on the topic. See UNCTAD PRINCIPLES, supra note 29. 
ante, well before the loan is entered into default. This building national consensus has prompted a shift in international focus on the issue. Recently, the G-20 has looked to more fully implement an international agreement on the "key objectives" of consumer financial protection regulation, including recommendation that lenders' assess their consumer borrowers' ability to repay such loans. ${ }^{256}$

Generally, a requirement to assess a consumer borrower's "ability to repay" is construed to impose obligations of review and due diligence on lenders. In some instances, failure to fulfill this obligation of responsible lending may excuse a borrower's subsequent default. Sovereign lenders might similarly be required to engage in a diligent ex ante assessment of a sovereign borrower's "ability to repay."

To some extent, the IMF "exceptional access" limits work in this way, but private sovereign lenders face no similar prescription. ${ }^{257}$ UNCTAD's Principles on Responsible Sovereign Lending recommend ex ante examination of sovereign loans, but nowhere compare sovereign borrowing to consumer borrowing and propose only limited due diligence in this context. ${ }^{258}$ The Principles are a start, however. Moreover, regulation of sovereign debt lending practices would constitute regulation of sovereign lenders, but not state actors. As a result, responsible sovereign lending regulation should raise fewer concerns regarding intrusions on sovereignty since, after all, it is the borrowers and not the lenders who are sovereign in the sovereign debt context.

\section{CONCLUSION}

Although there are important distinctions between extensions of consumer credit and sovereign lending, the metaphor to consumer

256. OECD, G-20 High-Level Principles on Financial Consumer Protection 7 (Oct. 14, 2011) ("Depending on the nature of the transaction and based on information primarily provided by customers financial services providers should assess the related financial capabilities, situation and needs of their customers before agreeing to provide them with a product, advice or service."), http://www.oecd.org/daf/fin/financial-markets/48892010.pdf. See also G20/OECD Taskforce on Consumer Finance Protection, Update Report on the Work to Support the Implementation of the G-20 High-Level Principles on Financial Consumer Protection, 14 (Sept. 2013) ("For financial products in general a consumer's ability to meet relevant payment obligations is assessed and verified before a transaction is concluded."), http://www.oecd.org/g20/topics/financial-sector-reform/G20Effective ApproachesFCP.pdf.

257. Existing voluntary standards on sovereign debt restructuring do not broach this

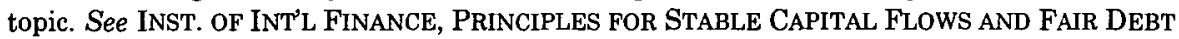
RESTRUCTURING IN EMERGING MARKETS (2004), https://www.iif.com/system/files/ principles-final_0305.pdf.

258. UNCTAD PRINCIPLES, supra note 29. 
lending nonetheless produces useful insights to sovereign debt markets. One important payoff from this shift in metaphor is to justify ex ante focus on sovereign lending practices. In assessing sovereign lending practices, the shift in metaphor directs us to examine consumer lenders' practices in extending credit on the basis of a borrower's income stream and not on the basis of the borrower's assets, as well as examine the profitability of this sort of "income-based" lending. ${ }^{259}$ Further, in analyzing ex post incentives to restructure sovereign debt and the implications of shifts in restructuring practices on ex ante borrowing, reference to the burgeoning scholarship on household debtors' overindebtedness and the reluctance to restructure would lend support to the notion that sovereign borrowers also overborrow, sovereign lenders overlend, and both wait too long to seek a remedy for excessive debts that sovereigns struggle to pay. 260

Whether the comparison of consumer to sovereign debt is more apt than a comparison of corporate to sovereign debt is less important than whether either perspective suggests reform proposals that might garner interest in the international community. Thinking outside existing paradigms might be just what sovereign debt markets need.

259. See, e.g., Liran Einav, Mark Jenkins \& Jonathan Levin, The Impact of Credit Scoring on Consumer Lending, 44 RAND J. EcoN. 249-74 (2013) (stating that the adoption of automated credit scoring at a large auto finance company showed that credit scoring resulted in better risk classification and more profitable lending practices).

260. See, e.g., Udo ReIfNer et al., OverIndebtedness in European Consumer LaW: PRINCIPLES FROM 15 EUROPEAN STATES (2012) (discussing debt structures in European consumer finance markets and comparing various laws for addressing overindebtedness). 